\title{
Induced Pluripotency and Epigenetic Reprogramming
}

\section{Konrad Hochedlinger ${ }^{1}$ and Rudolf Jaenisch ${ }^{2}$}

\begin{abstract}
${ }^{1}$ Howard Hughes Medical Institute at Massachusetts General Hospital, Department of Stem Cell and Regenerative Biology, Harvard University and Harvard Medical School, Boston, Massachusetts 02114; ${ }^{2}$ Whitehead Institute and Department of Biology, Massachusetts Institute of Technology, Cambridge, Massachusetts 02142
\end{abstract}

Correspondence: khochedlinger@helix.mgh.harvard.edu

\section{SUMMARY}

Induced pluripotency defines the process by which somatic cells are converted into induced pluripotent stem cells (iPSCs) upon overexpression of a small set of transcription factors. In this article, we put transcription factor-induced pluripotency into a historical context, review current methods to generate iPSCs, and discuss mechanistic insights that have been gained into the process of reprogramming. In addition, we focus on potential therapeutic applications of induced pluripotency and emerging technologies to efficiently engineer the genomes of human pluripotent cells for scientific and therapeutic purposes.

\section{Outline}

1 History of cellular reprogramming

2 Generation of iPSCs

3 Mechanisms underlying iPSC formation

4 Applications of iPSC technology in disease research
5 An unresolved issue: Are iPSCs equivalent to ES cells?

6 Concluding remarks

References

Editors: C. David Allis, Marie-Laure Caparros, Thomas Jenuwein, Danny Reinberg, and Monika Lachner Additional Perspectives on Epigenetics available at www.cshperspectives.org

Copyright (C 2015 Cold Spring Harbor Laboratory Press; all rights reserved; doi: 10.1101/cshperspect.a019448

Cite this article as Cold Spring Harb Perspect Biol 2015;7:a019448 


\section{OVERVIEW}

Somatic cell nuclear transfer experiments in animals showed that the genome of a differentiated cell remains equivalent to that of a fertilized egg. Consequently, differential gene expression responsible for the formation of the 200 cell types of our body is the result of reversible epigenetic changes that are imposed on the genome during development. This seminal discovery raised fundamental questions about the mechanisms by which a somatic genome is epigenetically reprogrammed to an early embryonic state. In addition, the marriage of cloning and embryonic stem cell technology provided a means to generate custom-tailored cells in potential therapeutic settings. Although ethical, legal, and biological barriers associated with somatic cell nuclear transfer prevented significant progress toward this goal over the past 10 years, it motivated attempts to directly reprogram adult cells into pluripotent cells. Indeed, this concept was realized in 2006 by the isolation of induced pluripotent stem cells (iPSCs) directly from skin cells. iPSCs are generated by activating a handful of embryonic genes in somatic cells, giving rise to cells that closely resemble embryonic stem cells without ever going through development. Studies on the process of induced pluripotency have yielded important insights into the mechanisms by which transcription factors and epigenetic regulators cooperate to establish cell fates during development. They further revealed an unexpected plasticity of the differentiated cell state and led to the successful interconversion of other differentiated cell types by activating alternative sets of genes. Importantly, iPSCs have been derived from human patients, raising the possibility that these cells could be used to study and, perhaps, treat degenerative diseases. 


\section{HISTORY OF CELLULAR REPROGRAMMING}

The discovery of induced pluripotency represents the synthesis of scientific principles and technologies that have been developed over the last six decades (Fig. 1) (Stadtfeld and Hochedlinger 2010). These are notably (1) the demonstration by somatic cell nuclear transfer (SCNT) that differentiated cells retain the same genetic information as early embryonic cells; (2) the development of techniques that allowed researchers to derive, culture, and study pluripotent cell lines; and (3) the observation that transcription factors are key determinants of cell fate whose enforced expression can switch one mature cell type into another. In this section, we will briefly summarize these three areas of research and the influence they have had on the generation of iPSCs.

\subsection{Nuclear Transfer and the Cloning of Animals}

During mammalian development, cells gradually lose potential and become progressively differentiated to fulfill the specialized functions of somatic tissues. For example, only zygotes and blastomeres of early morulae (Kelly 1977) retain the ability to give rise to all embryonic and extraembryonic tissues and are therefore called "totipotent," whereas cells of the inner cell mass (ICM) of the blastocyst give rise to all embryonic, but not to extraembryonic tissues, and are hence coined "pluripotent." Stem cells residing in adult tissues can only give rise to cell types within their lineage and are, depending on the number of cell types they produce, either called "multipotent" or "unipotent" (Table 1). On terminal differentiation, cells entirely lose their developmental potential.

During the 1950s and 1960s, Briggs and King established the technique of SCNT or "cloning" to probe the developmental potential of nuclei isolated from late-stage embryos and tadpoles by transplanting them into enucleated oocytes (Fig. 1) (Briggs and King 1952, 1957). This work, together with seminal experiments by John Gurdon (Gurdon 1962), showed that differentiated amphibian cells

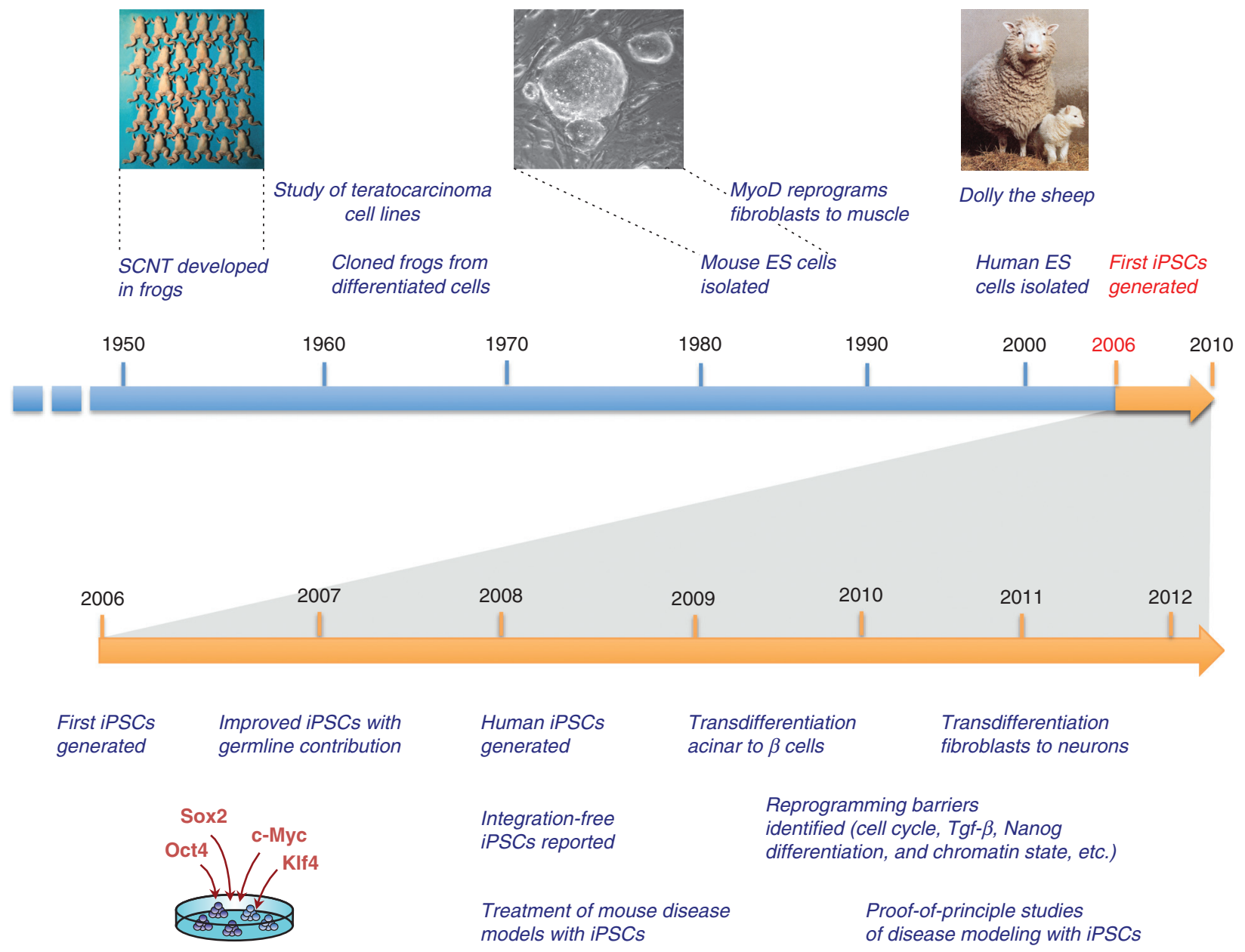

Figure 1. Historic time line of reprogramming research. Shown are seminal discoveries leading to the first generation of iPSCs in 2006, as well as progress in the generation and subsequent application of iPSCs. 
K. Hochedlinger and R. Jaenisch

Table 1. Definition of some terms

\begin{tabular}{|c|c|}
\hline Potency & $\begin{array}{c}\text { Sum of developmental options accessible } \\
\text { to the cell }\end{array}$ \\
\hline Totipotent & $\begin{array}{l}\text { Ability to form all lineages of the } \\
\text { organism; in mammals, only the zygote } \\
\text { and first cleavage blastomeres are } \\
\text { totipotent. }\end{array}$ \\
\hline Pluripotent & $\begin{array}{l}\text { Ability to form all lineages of the body } \\
\text { (e.g., embryonic stem cells). }\end{array}$ \\
\hline Multipotent & $\begin{array}{l}\text { Ability of adult stem cells to form multiple } \\
\text { cell types of one lineage (e.g., } \\
\text { hematopoietic stem cells). }\end{array}$ \\
\hline Unipotent & $\begin{array}{l}\text { Cells form one cell type } \\
\text { (e.g., spermatogonial stem cells, } \\
\text { which can only generate sperm). }\end{array}$ \\
\hline Reprogramming & $\begin{array}{l}\text { Increase in potency and dedifferentiation; } \\
\text { can be induced by nuclear transfer, cell } \\
\text { fusion, genetic manipulation. }\end{array}$ \\
\hline $\begin{array}{l}\text { Transdifferentiation, } \\
\text { plasticity }\end{array}$ & $\begin{array}{l}\text { Notion that somatic stem cells have } \\
\text { broadened potency and can generate } \\
\text { cells of other lineages, a concept that is } \\
\text { controversial in mammals. More } \\
\text { recently, transdifferentiation also refers } \\
\text { to transcription factor-induced } \\
\text { lineage conversions among } \\
\text { differentiated cell types. }\end{array}$ \\
\hline
\end{tabular}

indeed retain the genetic information necessary to support the generation of cloned frogs. The major conclusion from these experiments was that development imposes reversible epigenetic rather than irreversible genetic changes on the genome during cellular differentiation. The cloning of Dolly the sheep (Wilmut et al. 1997) and several other mammals from adult cells (Meissner and Jaenisch 2006) including terminally differentiated cells (Hochedlinger and Jaenisch 2002; Eggan et al. 2004; Inoue et al. 2005) showed that the genome of even fully specialized cells remains genetically totipotent (i.e., can support the development of an entire organism). However, most cloned animals show subtle to severe phenotypic and gene expression abnormalities, suggesting that SCNT results in faulty epigenetic reprogramming (Hochedlinger and Jaenisch 2003; see also Jaenisch and Gurdon 2007 for a detailed discussion of SCNT).

\subsection{Pluripotent Cell Lines and Fusion Hybrids}

Although SCNT is a powerful tool to probe the developmental potential of a cell, it is technically challenging and not well suited for genetic or biochemical studies. A major advance toward isolating iPSCs was the establishment of immortal pluripotent cell lines that maintained their ability to differentiate into essentially all cell types of the body when reintroduced into early embryos. Pluripotent stem cell lines were initially derived from teratocarcinomas, tumors of germ cell origin, giving rise to so-called embryonal carcinoma (EC) cells (Kleinsmith and Pierce 1964). Although EC cell lines fulfilled some pluripotency criteria (Table 2) such as teratoma formation and chimera contribution, they rarely contributed to the germline because of their tumorigenic origin. These findings motivated attempts to isolate pluripotent cell lines directly from embryos and subsequently led to the derivation of embryonic stem (ES) cells from the ICM of mouse and human blastocysts (Fig. 2) (Evans and Kaufman 1981; Martin 1981; Thomson et al. 1998). Mouse ES cells not only contribute

Table 2. Commonly used functional criteria to assess the developmental potential of cells

\begin{tabular}{|c|c|c|}
\hline Assay & $\begin{array}{l}\text { Experimental } \\
\text { approach }\end{array}$ & Limitations \\
\hline $\begin{array}{l}\text { In vitro } \\
\text { differentiation }\end{array}$ & $\begin{array}{l}\text { Differentiation is } \\
\text { induced in } \\
\text { cultured cells, and } \\
\text { cells are assayed } \\
\text { for the expression } \\
\text { of cell type- } \\
\text { specific markers. }\end{array}$ & $\begin{array}{l}\text { The expression of } \\
\text { differentiation } \\
\text { markers is no test } \\
\text { for functionality; } \\
\text { marker expression } \\
\text { can be due to } \\
\text { cellular stress } \\
\text { response. }\end{array}$ \\
\hline Teratoma formation & $\begin{array}{l}\text { The induction of } \\
\text { tumors shows the } \\
\text { potential to } \\
\text { generate } \\
\text { differentiated cell } \\
\text { types of various } \\
\text { lineages. }\end{array}$ & $\begin{array}{l}\text { Does not test for the } \\
\text { ability of cells to } \\
\text { promote normal } \\
\text { development. }\end{array}$ \\
\hline Chimera formation & $\begin{array}{l}\text { Cells injected into a } \\
\text { host blastocyst can } \\
\text { be assessed for } \\
\text { their contribution } \\
\text { to normal } \\
\text { development. }\end{array}$ & $\begin{array}{l}\text { Host-derived cells in } \\
\text { chimera may } \\
\text { complement cell } \\
\text { nonautonomous } \\
\text { defects. }\end{array}$ \\
\hline $\begin{array}{l}\text { Germline } \\
\text { contribution }\end{array}$ & $\begin{array}{l}\text { Ability of test cells } \\
\text { to generate } \\
\text { functional germ } \\
\text { cells. }\end{array}$ & $\begin{array}{l}\text { Excludes genetic, but } \\
\text { not epigenetic, } \\
\text { defects that could } \\
\text { interfere with } \\
\text { promoting } \\
\text { development. }\end{array}$ \\
\hline $\begin{array}{l}\text { Tetraploid } \\
\text { complementation }\end{array}$ & $\begin{array}{l}\text { Injection of test cells } \\
\text { into } 4 \mathrm{n} \text { host } \\
\text { blastocyst. Because } \\
4 \mathrm{n} \text { host cells } \\
\text { cannot contribute } \\
\text { to somatic } \\
\text { lineages, an } \\
\text { embryo is } \\
\text { exclusively } \\
\text { composed of test } \\
\text { cells. }\end{array}$ & $\begin{array}{l}\text { Most stringent test for } \\
\text { pluripotency; does } \\
\text { not test for the } \\
\text { ability to form the } \\
\text { trophectoderm } \\
\text { (placental) lineage. }\end{array}$ \\
\hline
\end{tabular}



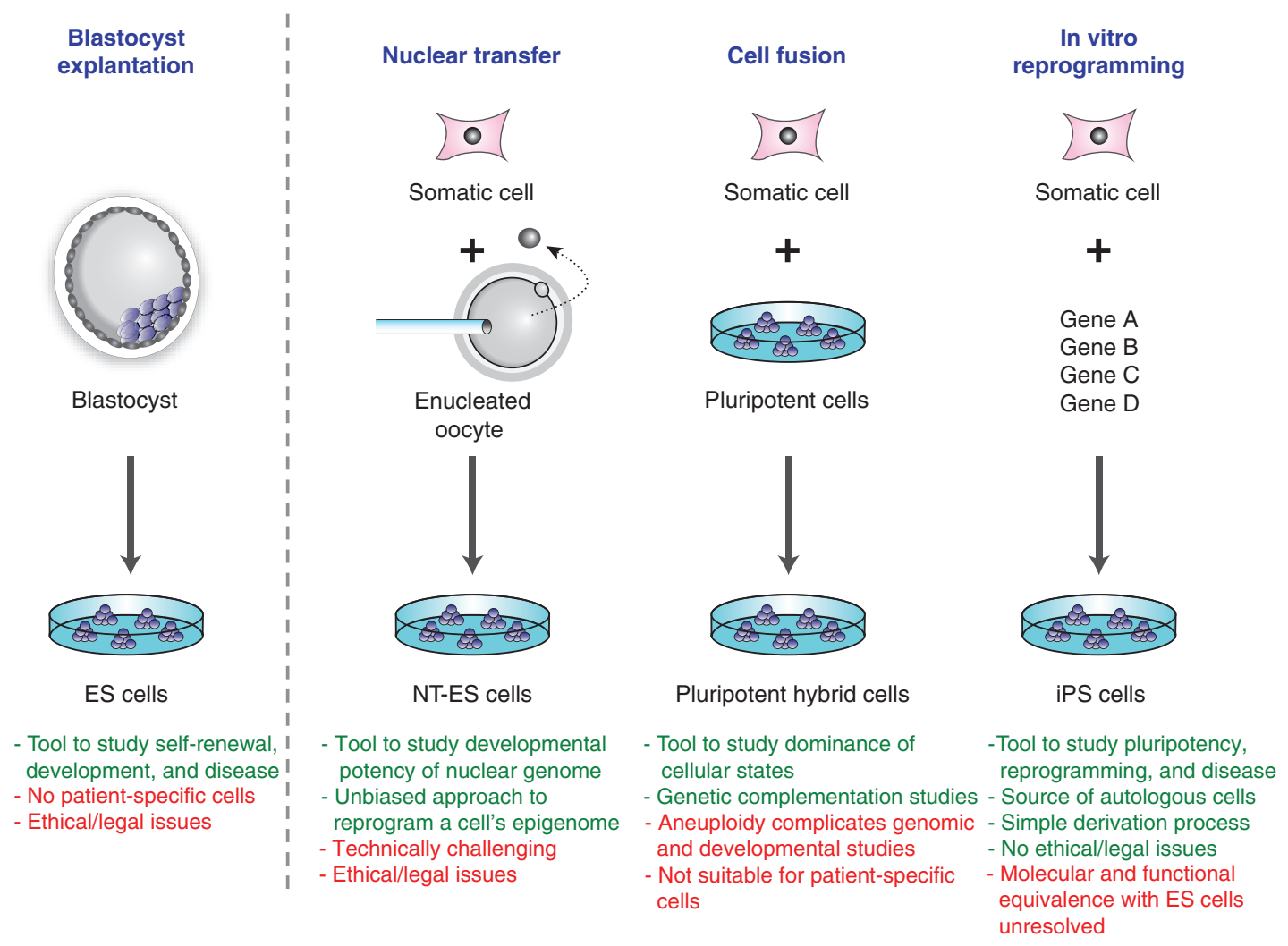

Figure 2. Sources of pluripotent stem cells. Comparison of different strategies used to derive pluripotent stem cell lines; their advantages (in green) or disadvantages (in red) are summarized at the bottom of each column. ES cells, embryonic stem cells; NT-ES cells, nuclear transfer-ES cells.

to adult tissues, including germ cells in chimeric mice, but also support the development of entirely ES cell-derived animals after injection into tetraploid blastocysts (Nagy et al. 1990; Eggan et al. 2001). Tetraploid blastocysts are generated by electrofusion of fertilized two-cell embryos; these embryos can only develop into extraembryonic tissues (i.e., the placenta), but fail to give rise to the fetus. This "tetraploid complementation assay" (referred to in Table 2) represents the most stringent developmental assay available in the mouse to test for pluripotency. ES cell lines can also be derived from cloned mouse (Munsie et al. 2000; Wakayama et al. 2001) and human (Tachibana et al. 2013) blastocysts generated by SCNT, generating so-called NT-ES cells (Fig. 2). In contrast to the abnormalities seen in directly cloned animals, NT-ES cells are molecularly and functionally indistinguishable from fertilization-derived ES cells, presumably because of a selection of faithfully reprogrammed cells in culture (Brambrink et al. 2006; Wakayama et al. 2006).

The study of hybrids generated by cell fusion between different cell types has also been instrumental for the identification of factors that could directly induce pluripotency in somatic cells (Yamanaka and Blau 2010). Specifically, when EC or ES cells are fused with somatic cells, the resulting hybrid cells acquire biochemical and developmental properties of pluripotent cells and extinguish features of the somatic fusion partner (Fig. 2) (Miller and Ruddle 1976; Tada et al. 2003). This dominance of the pluripotent state over the somatic state in hybrids suggested that soluble transacting factors must exist within pluripotent cells that can confer a pluripotent state on somatic cells and these factors should be identifiable (Yamanaka and Blau 2010).

\subsection{Transcription Factors and Lineage Switching}

The third principle that contributed to the discovery of induced pluripotency was the observation that lineageassociated transcription factors can change cell fate when ectopically expressed in certain heterologous cells. Transcription factors help to establish and maintain cellular identity during development by driving the expression of cell type-specific genes while suppressing lineage-inappropriate genes. This principle was first shown by the formation of myofibers in fibroblast cell lines transduced with retroviral vectors expressing the skeletal muscle transcription factor MyoD (Davis et al. 1987). Subsequently, Graf 
and colleagues discovered that primary B and T cells could be efficiently converted into functional macrophages on overexpression of the myeloid transcription factor $\mathrm{C} / \mathrm{EBP} \alpha$ (Xie et al. 2004; Laiosa et al. 2006). More recently, researchers have identified sets of transcription factors that induce the conversion of pancreatic acinar cells into insulin-producing $\beta$ cells by overexpressing the pancreatic factors MafA, Pdx,1 and Ngn3 (Zhou et al. 2008). Similarly, the conversion of fibroblasts into neurons can be achieved by the activation of the neural factors Ascl1, Brn2, and Myt1l (Vierbuchen et al. 2010); fibroblasts can be made into cardiomyocytes by the cardiac factors Gata4, Mef2c, and $T b x 5$ (Ieda et al. 2010); and fibroblasts can be converted into hepatocytes on overexpression of HNF1alpha, Foxa3, and optionally Gata4 factors (Huang et al. 2011). The early muscle and immune cell transdifferentiation experiments provided the intellectual framework for a more systematic search for transcription factors that could induce the conversion of differentiated cells to a pluripotent state as discussed below (see also Takahashi 2014).

\section{GENERATION OF iPSCs}

\subsection{Screen for Reprogramming Factors}

To identify transcriptional regulators that are sufficient for reprogramming adult cells into pluripotent cells, Yamanaka and Takahashi devised an elegant screen for factors that could activate a dormant drug resistance allele integrated into the ES cell-specific Fbxo15 locus (Fig. 3). This selection approach was chosen to ensure that potentially rare reprogrammed cells could be detected and nonreprogrammed colonies and transformed cells would be eliminated. The investigators selected 24 genes that were specifically expressed in pluripotent cells or had previously been implicated in ES cell biology. The combination of all 24 factors, when coexpressed from retroviral vectors in mouse fibroblasts, indeed activated Fbxo15 and induced the formation of drug-resistant colonies with characteristic ES cell morphology, albeit at extremely low efficiencies $(0.01 \%-$ 0.1\%; Fig. 3) (Takahashi and Yamanaka 2006). Successive rounds of elimination of individual factors from the gene cocktail then led to the identification of the minimally required core set of four factors, Klf4, Sox2, c-Myc, and Oct4. iPSCs generated by this selection approach also expressed markers of pluripotent stem cells such as the surface antigen SSEA-1 and Nanog, generated teratomas when injected subcutaneously into immunocompromised mice, and contributed to different tissues of the developing embryo upon blastocyst injection, thereby meeting some criteria of pluripotency (Table 2). However, these iPSCs expressed lower levels of several other key pluripotency genes compared to ES cells, showed incomplete reprogramming of

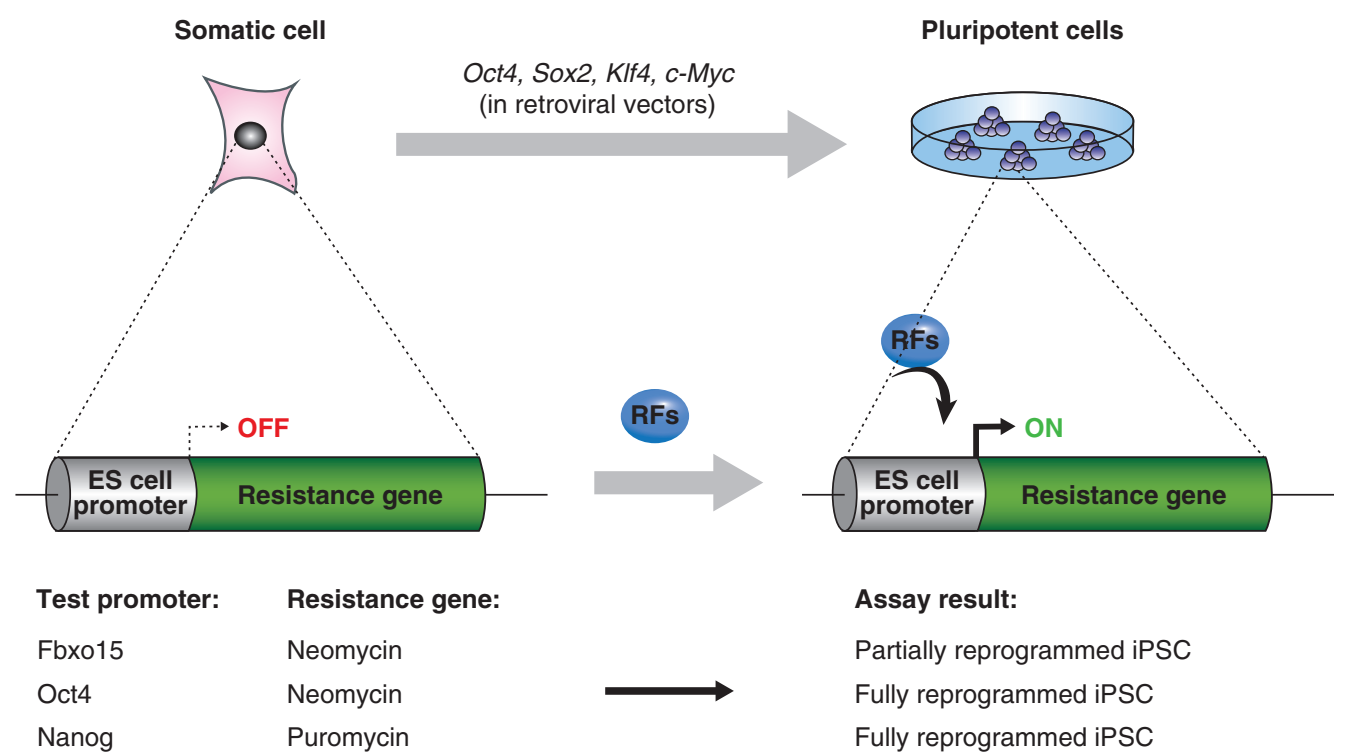

Figure 3. Strategy to derive iPSCs. (Top) Schematic representation of the first successful attempt to produce iPSCs by Takahashi and Yamanaka. (Bottom) The genetic assay system used to screen for factors that could reprogram to pluripotency (reprogramming factors $[R F s]$ ). Partial reprogramming to iPSCs was achieved by viral infection of cells with Oct4, Sox2, Klf4, and c-Myc, followed by drug selection for Fbxo15-expressing cells. In contrast, subsequent modifications to the assay selecting for Oct4- or Nanog-expressing cells gave rise to fully reprogrammed iPSCs. Note that drug selection is not essential for producing high-quality iPSCs, but was used as part of the assay to identify factors that induced embryonic gene expression (see text). 
epigenetic marks, and failed to generate postnatal chimeras or contribute to the germline. These initially derived iPSCs therefore appeared to be partially reprogrammed.

Soon after this report, several laboratories including Yamanaka's were able to reproduce and improve upon these findings. For example, by selecting for the reactivation of the essential pluripotency genes Nanog or Oct4 instead of Fbxo15, iPSCs were generated that molecularly and functionally more closely resembled ES cells (Fig. 3) (Maherali et al. 2007; Okita et al. 2007; Wernig et al. 2007). More recently, iPSCs have been identified that are even capable of generating "all-iPSC" mice after injection into tetraploid blastocysts (Table 2) (Boland et al. 2009; Kang et al. 2009; Zhao et al. 2009), thus suggesting that at least some iPSC clones have a developmental potency equivalent to that of ES cells.

Importantly, high-quality mouse iPSCs can be derived from genetically unmodified somatic cells without drug selection by simply using morphological criteria (Blelloch et al. 2007; Maherali et al. 2007; Meissner et al. 2007). This discovery was critical for extending induced pluripotency to other species for which transgenic tools were not readily available. For example, iPSCs have been successfully generated from human (Takahashi et al. 2007; Yu et al. 2007; Park et al. 2008), rat (Li et al. 2009b), and rhesus monkey fibroblasts (Liu et al. 2008) by expression of the same four Yamanaka factors, demonstrating that fundamental features of the transcriptional network governing pluripotency remain conserved during evolution. In addition, iPSCs have been derived from other somatic cell populations such as keratinocytes (Aasen et al. 2008; Maherali et al. 2008), neural cells (Eminli et al. 2008; Kim et al. 2008), stomach and liver (Aoi et al. 2008), as well as from genetically labeled pancreatic $\beta$ cells (Stadtfeld et al. 2008a), melanocytes (Utikal et al. 2009a), and terminally differentiated B and T lymphocytes (Hanna et al. 2008b; Eminli et al. 2009), thus underscoring the generality of induced pluripotency across different cell types.

\subsection{Genetically Unmodified iPSCs}

Retroviral transgenes used to deliver the reprogramming factors are usually silenced toward the end of reprogramming (Stadtfeld et al. 2008b) by a mechanism that involves DNA (Lei et al. 1996) and histone methylation (Matsui et al. 2010). However, this process is often incomplete, resulting in partially reprogrammed cell lines that fail to activate endogenous pluripotency genes and therefore continue to depend on transgenic reprogramming factor expression for indefinite growth (Takahashi and Yamanaka 2006; Mikkelsen et al. 2008; Sridharan et al. 2009). In addition, residual activity or reactivation of viral transgenes in
iPSC-derived somatic cells can interfere with their developmental potential and frequently leads to the formation of tumors in chimeric animals (Okita et al. 2007). These shortcomings spurred efforts to derive iPSCs devoid of viral vector sequences. The first integration-free iPSCs were generated from adult mouse hepatocytes using nonintegrating adenoviral vectors (Stadtfeld et al. 2008c) and from mouse embryonic fibroblasts (MEFs) after transfection with plasmids (Okita et al. 2008) or RNA viruses (Fusaki et al. 2009) that persisted only transiently inside cells. Importantly, chimeric animals produced from integrationfree iPSCs were tumor-free. Alhough these methods were extremely inefficient, they led to two important conclusions. First, viral integration and insertional mutagenesis are not required for stable cellular reprogramming. Second, direct reprogramming does not necessarily generate pluripotent cells of poorer quality or compromised safety than ES cells. However, it is important in all of these approaches to completely exclude the possibility that vector fragments or RNA viruses persisted in the resulting iPSCs.

Various new methods have been developed to generate genetically unmodified or "reprogramming factor-free" human iPSCs with alternative technologies. These include transfection with messenger RNA (mRNA) instead of DNA, replacement of factors by small molecules, and delivery of factors as recombinant proteins or extracts. The extremely low efficiency of reprogramming cells with recombinant proteins (Zhou et al. 2009) or extracts (Kim et al. 2009a) makes this an impractical strategy for iPSC generation. Another approach has used modified mRNA constructs to express the reprogramming factors in somatic donor cells, giving rise to human iPSCs (Warren et al. 2010). This method is efficient in yielding factor-free iPSCs and thus may be the preferred method for reprogramming. Last, a variety of small molecules have been shown to replace individual reprogramming factors (Huangfu et al. 2008; Xu et al. 2008; Ichida et al. 2009; Lyssiotis et al. 2009). Remarkably, the combination of certain compounds is sufficient to induce pluripotency in somatic cells according to a recent report (Hou et al. 2013).

In summary, the generation of genetically unmodified vector-free iPSCs has been resolved in principle. It is likely that, for a given application, one of the various strategies outlined above may be more optimal than another.

\subsection{Reprogrammable Mice}

A technical advance for studying molecular mechanisms of reprogramming has been the development of so-called "secondary reprogramming systems" and "reprogrammable mice" (Fig. 4). This approach entails differentiating "primary" iPSC clones using either in vitro differentiation for 


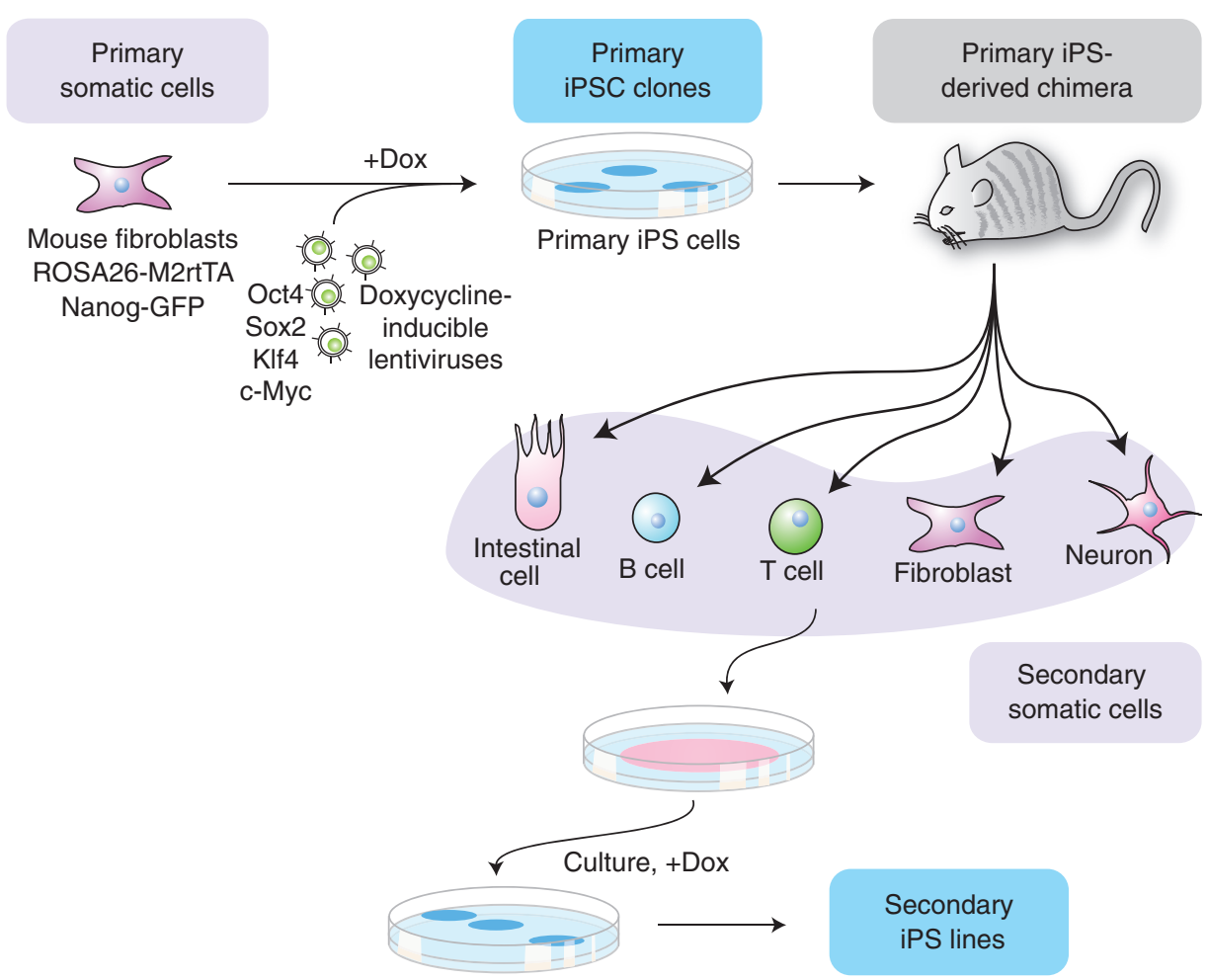

Figure 4. Generation of genetically homogeneous cell cultures for epigenetic reprogramming. Scheme for obtaining genetically homogeneous somatic cells that are more efficient at pluripotency induction. Primary somatic cells with stable integrations of a Nanog-GFP (green fluorescent protein) marker and reverse tetracycline transactivator (M2rtTA) are infected with DOX-inducible lentiviruses encoding the four reprogramming factors. Primary iPSCs are generated by culturing the cells in DOX to activate the factors. After DOX withdrawal, the primary iPSCs are injected into mouse blastocysts and "secondary" somatic cells carrying the DOX-inducible vectors are cultured in the presence of DOX to produce secondary iPSCs. The key advantage of this system is that reprogramming can be induced without new virus infection at a much higher efficiency. (Modified, with permission, from Hanna et al. 2008a.)

human cells (Hockemeyer et al. 2008; Maherali et al. 2008) or blastocyst injection for mice (Wernig et al. 2008; Woltjen et al. 2009). Primary iPSCs were generated by introducing the Yamanaka transcription factor cocktail carried on doxycyline-inducible lentiviral vectors or transposons into somatic cells. These genetically homogeneous differentiated cells are then cultured in doxycycline-containing media, thus triggering the formation of "secondary" iPSCs at efficiencies that are generally several orders of magnitude higher $(1 \%-5 \%)$ than the efficiencies obtained after primary infection $(0.01 \%-1 \%)$. This observation showed that the low efficiency of reprogramming is not solely the result of ineffective transduction of somatic cells by all four viral vectors as had originally been assumed. It is instead consistent with the notion that other, presumably epigenetic, roadblocks must exist to limit the acquisition of pluripotency.

In a modification of the conventional secondary system, "reprogrammable" mouse strains have been developed that contain a single doxycycline-inducible polycistronic transgene that has been targeted to a defined genomic position by homologous recombination. This system does not de- pend on viral infection anymore and facilitates the derivation of iPSCs from virtually any cell type of the mouse by simply adding doxycycline to the culture medium (Carey et al. 2010; Stadtfeld et al. 2010b).

\section{MECHANISMS UNDERLYING IPSC FORMATION}

In the following section, we introduce models that have been developed to explain the low efficiency of reprogramming at a cellular level. We then discuss key molecular events that act as barriers during the reprogramming process and speculate on the role of the individual reprogramming factors.

\subsection{Deterministic versus Stochastic Models}

Two main models have been put forward to explain the reprogramming process (Fig. 5A) (Yamanaka 2009). The "deterministic" model posits that individual somatic cells synchronously convert into iPSCs with a constant latency 


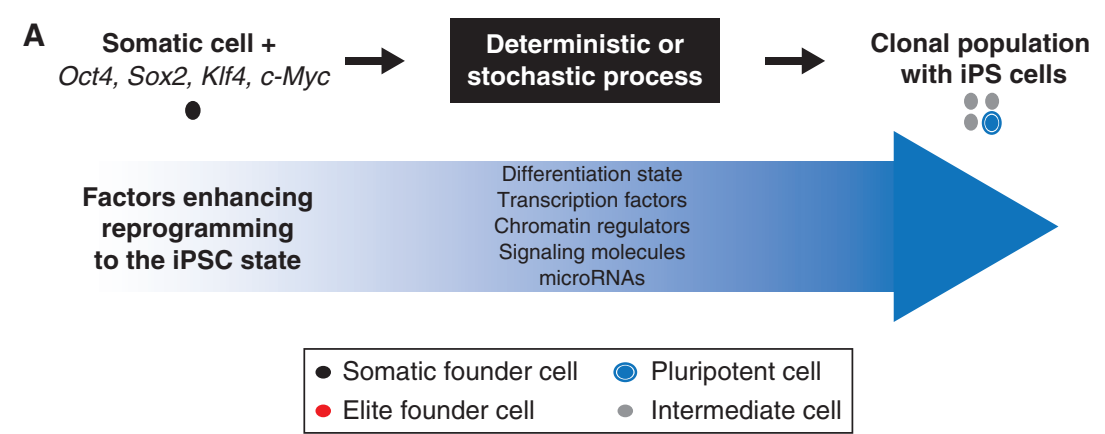

B Deterministic models
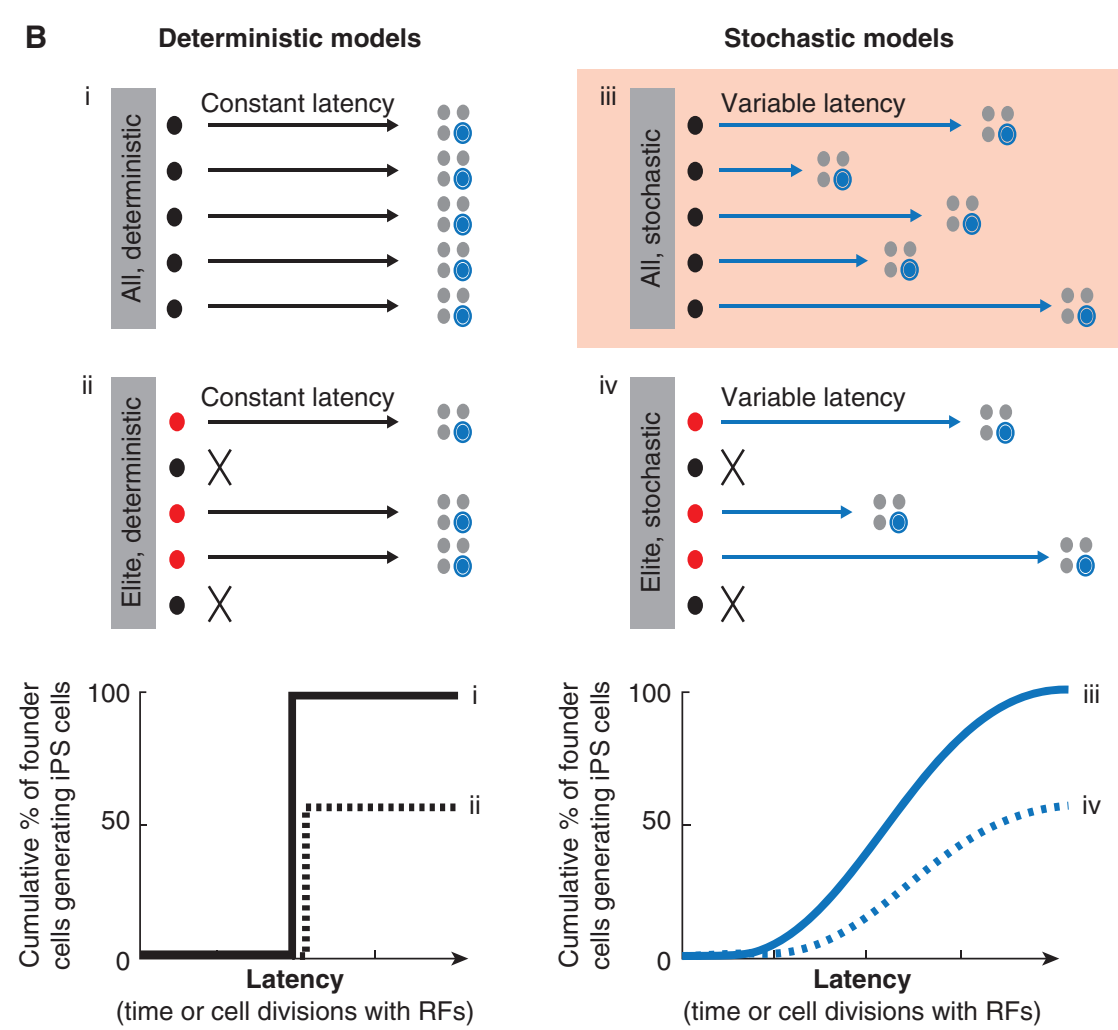

Figure 5. Stochastic and deterministic models of cellular reprogramming into iPSCs. (A) Schematic representation of the reprogramming process. $(B)$ Representation of four possible models to explain the low efficiency of reprogramming. The deterministic model posits that (i) all somatic cells or (ii) a subset of somatic cells termed elite founder cells gives rise to iPSCs with the same predetermined latency. In contrast, the stochastic model predicts that (iii) all cells or (iv) a subpopulation of "elite" cells produces iPSCs with different latencies. Latency can be measured in elapsed time or number of cell divisions necessary to activate pluripotency genes. Expected outcomes for the individual models are shown at the bottom. Experimental evidence using clonal B cell and monocyte populations supports a stochastic model of type "iii" (highlighted; see text for details). RFs, reprogramming factors. (Modified, with permission, from Hanna et al. 2009b.)

(or number of cell divisions; models $\mathrm{i}$ and ii in Fig. 5B) whereas the "stochastic" model predicts that somatic cells give rise to iPSCs with variable latencies or after going through different numbers or cell division (models iii and iv). In addition, one has to consider whether all somatic cells or only a few "elite" cells will yield iPSCs; somatic stem or progenitor cells that are present in most adult tissues, and possibly persist in explanted cell populations, are the most obvious candidate "elite" cells as they are rare and developmentally closer to pluripotent cells than differentiated cells.

Reprogramming is unlikely to follow a purely deterministic process in all cells (model i) as this disagrees with the low efficiency of iPSC formation. Models based exclusively on an elite component (models ii or iv) are also difficult to sustain because iPSCs can be derived from many different 
somatic cells including fully differentiated B and T lymphocytes (Hanna et al. 2008b; Eminli et al. 2009) as well as pancreatic $\beta$ cells (Stadtfeld et al. 2008a). Moreover, when following clonal populations of early B cells and monocytes expressing the reprogramming factors, almost all cell clones ultimately give rise to daughter cells that form iPSCs, although this process requires continuous growth over several weeks to months (Hanna et al. 2009b). The latter observation suggested that continuous cell proliferation allows rare cells in almost every clonal cell population to acquire molecular changes that facilitate their conversion into a pluripotent state. These findings, combined with mathematical modeling, support a stochastic model of cellular reprogramming (i.e., the highlighted model iii in Fig. 5B) (Hanna et al. 2010b).

Interestingly, the overexpression of the pluripotency factor Nanog in combination with the standard Yamanaka factors, Oct4, Sox2, Klf4, and c-Myc enhances cellular reprogramming in a cell division-independent manner (Hanna et al. 2009b). This result indicated that cellular reprogramming is amenable to acceleration by additional treatments. Consistently, several other factors have been identified wherein overexpression or depletion during cellular reprogramming increased the generation of iPSCs (Fig. 5A). These molecules include transcription factors (e.g., Tbx3, Sall4, Glis1), chromatin regulators (e.g., UTX, BAF, Dnmt1, Mbd3), microRNAs (e.g., miR-294, miR302/367), and signaling molecules (e.g., Wnt, Tgf- $\beta$, Jak/ Stat) (Stadtfeld and Hochedlinger 2010; Maekawa et al. 2011; Orkin and Hochedlinger 2011; Mansour et al. 2012).

Another parameter that has been shown to contribute to the efficiency of reprogramming is the differentiation state of the starting cell. For example, clonally plated hematopoietic stem and progenitor cells give rise to iPSCs with significantly higher efficiencies than mature lymphocytes and myeloid cells $(10 \%-40 \%$ vs. $0.01 \%$ to $1 \%$; Eminli et al. 2009; Stadtfeld et al. 2010b). Similarly, subpopulations of fibroblasts produce iPSCs sooner and more efficiently than the bulk population when following individual cells with live cell imaging (Smith et al. 2010) or upon sorting of immature cells with surface markers (Nemajerova et al. 2012). In conclusion, cellular reprogramming is most consistent with a stochastic model. However, additional parameters such as differentiation stage, growth factors, and the supplementation of other transcription factors can influence this process.

\subsection{Molecular Changes during Cellular Reprogramming}

The low efficiency and slow kinetics of iPSC derivation are in stark contrast to somatic cell lineage switching triggered by transcription factor overexpression, such as the conversion of $\mathrm{B}$ cells into macrophages induced by $\mathrm{C} / \mathrm{EBP} \alpha$, which occurs at efficiencies of up to $100 \%$ and within 48 hours (Bussmann et al. 2009). This suggests that the induction of pluripotency by defined factors faces more barriers than lineage conversion, possibly because of a higher degree of transcriptional and epigenetic similarity among mature cell types than between mature cells and pluripotent cells. Thus, what are the major molecular roadblocks a somatic cell faces during reprogramming into an iPSC?

\subsubsection{Silencing of Somatic Genes and Activation of Pluripotency Genes}

Studies in fibroblasts suggest that reprogramming follows an organized sequence of events that begins with the downregulation of somatic markers (Stadtfeld et al. 2008b) and morphological changes reminiscent of a mesenchymal-toepithelial transition (MET) (Fig. 6) (Li et al. 2010; Samavarchi-Tehrani et al. 2010). In accordance, interference with genes involved in MET such as the epithelial molecule Ecadherin and bone morphogenetic protein (BMP) receptor signaling abrogate reprogramming. These events are followed by the activation of the early pluripotency markers SSEA-1, alkaline phosphatase, and Fbxo15 before bona fide pluripotency genes such as Nanog or Oct4 become expressed (Fig. 6) (Brambrink et al. 2008; Stadtfeld et al. 2008b). The telomerase enzyme, responsible for extending the shortened telomeres of somatic cells, is reactivated at the same time as endogenous Nanog and Oct4.

Reprogramming intermediates isolated based on combinations of the aforementioned markers have an increased probability to form iPSC colonies (Stadtfeld et al. 2008b), suggesting that these cells have overcome several transcriptional and epigenetic barriers that normally prevent the induction of pluripotency. Interestingly, the majority of fibroblasts expressing reprogramming factors fail to down-regulate somatic markers and activate pluripotency genes (Wernig et al. 2008; Stadtfeld et al. 2010b), indicating that many cells become refractory to reprogramming. Such "nonresponding" fibroblasts do not give rise to iPSCs even after prolonged culture. Collectively, these results suggest that the extinction of the somatic program and the subsequent activation of endogenous pluripotency genes represent roadblocks during iPSC formation. In support of this conclusion, the down-regulation of genes that stabilizes the differentiated state (e.g., Pax5, Pax7, Gata6) (Hanna et al. 2008b; Mikkelsen et al. 2008) or the ectopic expression of other pluripotency factors in combination with Oct4, Sox2, Klf4, and c-Myc has been shown to enhance iPSC formation (Stadtfeld and Hochedlinger 2010). 


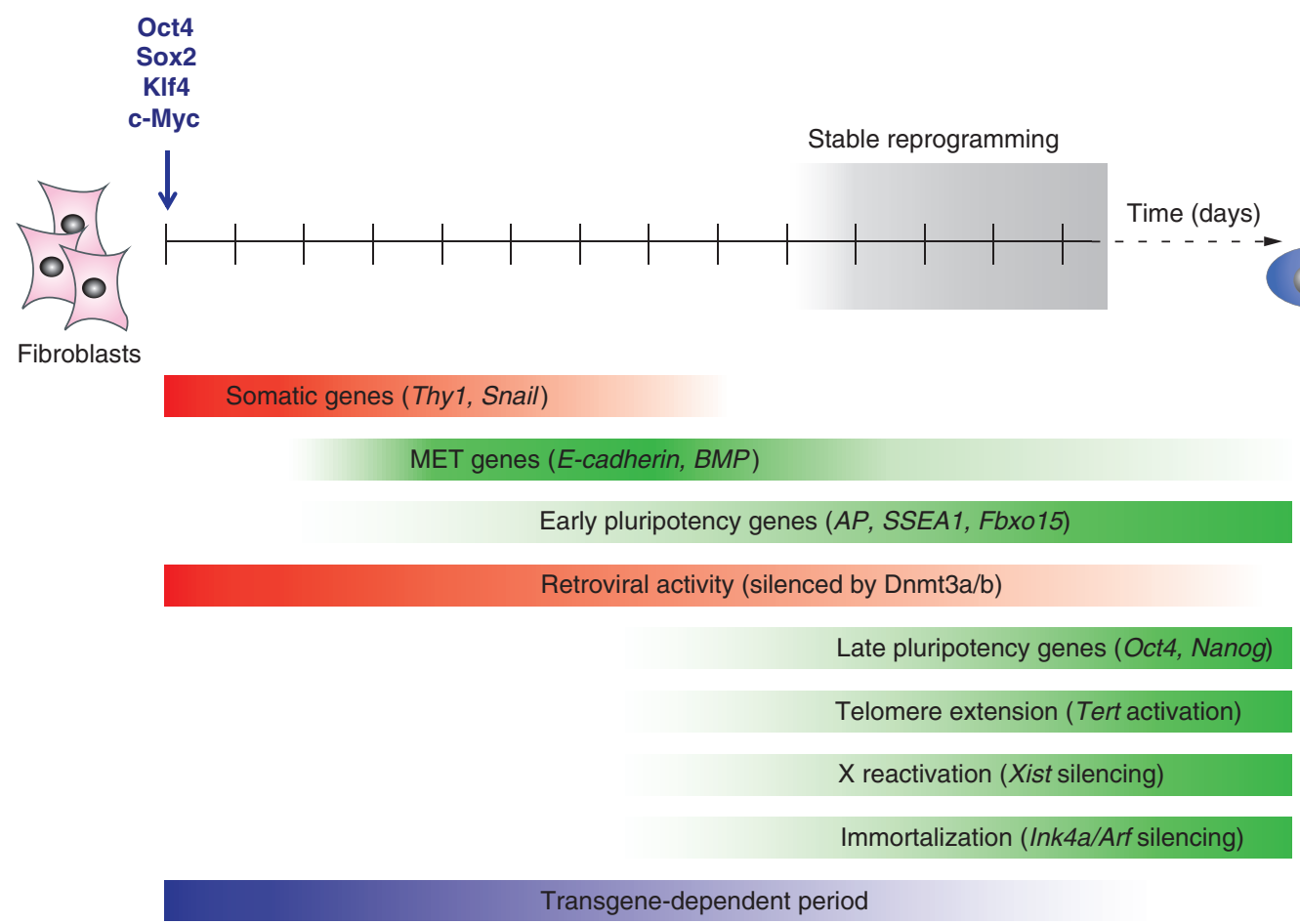

Figure 6. Molecular and cellular cornerstones of cellular reprogramming into iPSCs. Depicted are key events and examples of genes that are regulated during the reprogramming of fibroblasts to pluripotency. "Stable reprogramming" indicates the time window when cells activate endogenous pluripotency loci and become transgene independent. MET, mesenchymal-to-epithelial transition. (Adapted, with permission, from Stadtfeld et al. 2008b.)

\subsubsection{Resetting of Global Histone and DNA Methylation Patterns}

Gene expression in somatic and differentiated cells is maintained by characteristic patterns of DNA methylation and histone tail modifications. In general, pluripotency genes such as Oct4 and Nanog are silenced in somatic cells by both repressive histone modifications such as histone $\mathrm{H} 3$ lysine 27 trimethylation (H3K27me3) and DNA methylation. In contrast, in pluripotent cells, the Oct4 promoter is devoid of promoter DNA methylation and carries the activating histone mark $\mathrm{H} 3$ lysine 4 trimethylation (H3K4me3). Successful reprogramming requires resetting of both of these epigenetic modifications from a somatic to a pluripotent state at a genome-wide level. Genome-wide analyses (chromatin immunoprecipitation, ChIP) combined with deep sequencing (ChIP-seq) of iPSCs revealed that the overall histone modification and DNA methylation landscapes are correctly reprogrammed in most authentic iPSC lines, whereas they are incompletely restored in partially reprogrammed iPSCs (Maherali et al. 2007; Mikkelsen et al. 2008; Sridharan et al. 2009). A number of histone-modifying enzymes have recently been discovered that are involved in this process. For example, the histone lysine $(\mathrm{K})$ demethylase UTX, which removes inhibitory H3K27 meth- ylation marks from silenced pluripotency loci, is critical for efficient iPSC formation (Mansour et al. 2012). Likewise, components regulating the activating $\mathrm{H} 3 \mathrm{~K} 4$ mark such as WD repeat domain 5 (Wdr5) influence efficient reprogramming by ensuring proper expression of key pluripotency genes (Ang et al. 2011).

DNA methylation patterns are established during mammalian development by the de novo methyltransferases Dnmt3a and Dnmt3b and are maintained throughout adulthood by the maintenance methyltransferase Dnmt1 (Reik et al. 2001). Loss of the DNA maintenance methylation machinery is incompatible with embryonic development (Li et al. 1992). Surprisingly, iPSC formation is not affected in the absence of Dnmt3a and Dnmt3b, indicating that de novo methylation is dispensable for cellular reprogramming (Pawlak and Jaenisch 2011). It is likely that other repressive mechanisms such as histone modifications compensate for the loss of de novo methylation. In contrast, reducing global genomic methylation levels, by either using short hairpins against Dnmt1 or treating cells with the demethylating drug 5-aza-cytidine, boosts cellular reprogramming (Mikkelsen et al. 2008). Specifically, these treatments enhance overall colony formation and facilitate the conversion of partially reprogrammed iPSCs into fully reprogrammed iPSCs. Although the underlying mechanisms 
remain unclear, it is likely that DNA demethylation enhances reprogramming through the derepression of pluripotency genes such as Oct4 and Nanog. Together, these results show that DNA demethylation rather than the acquisition of methylation provides additional barriers to cellular reprogramming.

\subsection{Importance of Cell Proliferation}

In contrast to ES cells, which grow indefinitely in culture, fibroblasts have a restricted proliferative potential and eventually undergo apoptosis, growth arrest, or stress-induced senescence because of activation of the tumor-suppressor genes p53 and Ink4a/Arf (Collado et al. 2007). Indeed, expression of the Yamanaka factors in $p 53$ or Ink4a/Arfdeficient fibroblasts, which fail to senesce and hence proliferate indefinitely, leads to a dramatic increase in iPSC colony numbers (Banito et al. 2009; Hong et al. 2009; Kawamura et al. 2009; Li et al. 2009a; Utikal et al. 2009b). It is important to note, however, that different cell types expressing the four factors elicit different responses upon loss of p53. In fibroblasts, the main effect of p53 loss appears to be the inhibition of senescence and cell death, whereas in blood cells that express the same reprogramming factors, the loss of p53 mainly contributes to reprogramming by accelerating cell cycle (Hanna et al. 2009b). This finding emphasizes the fact that barriers inherent to cellular reprogramming can be cell context-dependent.

The acquisition of pluripotency may not be complete on attaining independence from exogenous Yamanaka factor expression; the full activation of pluripotency genes may require several rounds of cell divisions, as suggested by the finding that early- and late-passage iPSCs show discernible differences in telomere length (Marion et al. 2009) and global changes in transcription and DNA methylation patterns (Chin et al. 2009; Polo et al. 2010). This finding is consistent with the notion that freshly derived iPSC lines show an "epigenetic memory" that is characterized by residual epigenetic marks and gene expression signatures inherited from the somatic cell of origin (Kim et al. 2010; Polo et al. 2010).

\subsection{Transcription Factors Maintain the Pluripotent State of ES Cells}

Oct4, Nanog, and Sox 2 form a core of transcription factors that maintain ES cells in a self-renewing and undifferentiated state that is poised for differentiation. Accordingly, deletion of any of these factors in ES cells abrogates or severely compromises ES cell self-renewal (Chambers and Smith 2004). Studies analyzing the occupancy of these factors across the genome in mouse and human ES cells indi- cates that they serve two main purposes: their association with a particular genomic region controls either the repression of genes associated with differentiation or the activation of ES cell-specific targets (Fig. 7A) (Jaenisch and Young 2008). Gene suppression by pluripotency factors in ES cells is at least in part mediated by the recruitment to target promoters of repressive chromatin remodeling complexes such as the histone deacetylase-containing NuRD complex (Kaji et al. 2006) and the lysine methyltransferase-containing Polycomb complex 2 (Boyer et al. 2006; Lee et al. 2006), leading to repressive histone deacetylation and $\mathrm{H} 3 \mathrm{~K} 27 \mathrm{me} 3$, respectively.

This dual control of target gene regulation might explain why somatic genes are usually silenced before pluripotency genes become activated during iPSC formation. Although repressive complexes can immediately form upon binding of individual reprogramming factors to target sites, key components of the more elaborate activating complexes such as Nanog or Daxl (Wang et al. 2006) may be limiting or absent at early stages of reprogramming and only become available once their respective endogenous genomic loci have been transcriptionally activated (Fig. 7B). This process might be facilitated by nucleosome remodelers such as Chd1 (Gaspar-Maia et al. 2009) and BAF (Singhal et al. 2010); indeed, both of these molecules have been shown to enhance reprogramming efficiencies when overexpressed. Once the majority of core pluripotency factors are expressed, they presumably engage in positive-feedback loops (Jaenisch and Young 2008) to sustain pluripotency in the absence of exogenous factor expression (Fig. 7A).

\subsection{Contributions of Individual Factors to Cellular Reprogramming}

Studies on partially reprogrammed cells suggest that the inability of Oct4, Sox2, and Klf4 to bind to their targets is a limiting factor for acquiring pluripotency (Sridharan et al. 2009). In contrast, c-Myc efficiently occupies targets associated with proliferation and metabolism, indicating that cMyc plays a distinct role compared with Oct4, Sox2, and Klf4 (see cell-cycle gene in Fig. 7B). Accordingly, c-Myc expression is only required for the first few days of reprogramming (Sridharan et al. 2009), whereas Sox 2 expression is essential only at late stages (Chen et al. 2011). In further agreement with a supportive role of c-Myc during early steps in reprogramming, premature expression of c-Myc and Klf4 in fibroblasts before activation of all four factors increases reprogramming efficiencies and speed, whereas early expression of Sox2 and Oct4 has no effect (Markoulaki et al. 2009). Mechanistically, c-Myc expression might enhance reprogramming by facilitating the binding of Oct 4 and Sox2 to cognate targets-for example, by establishing or 

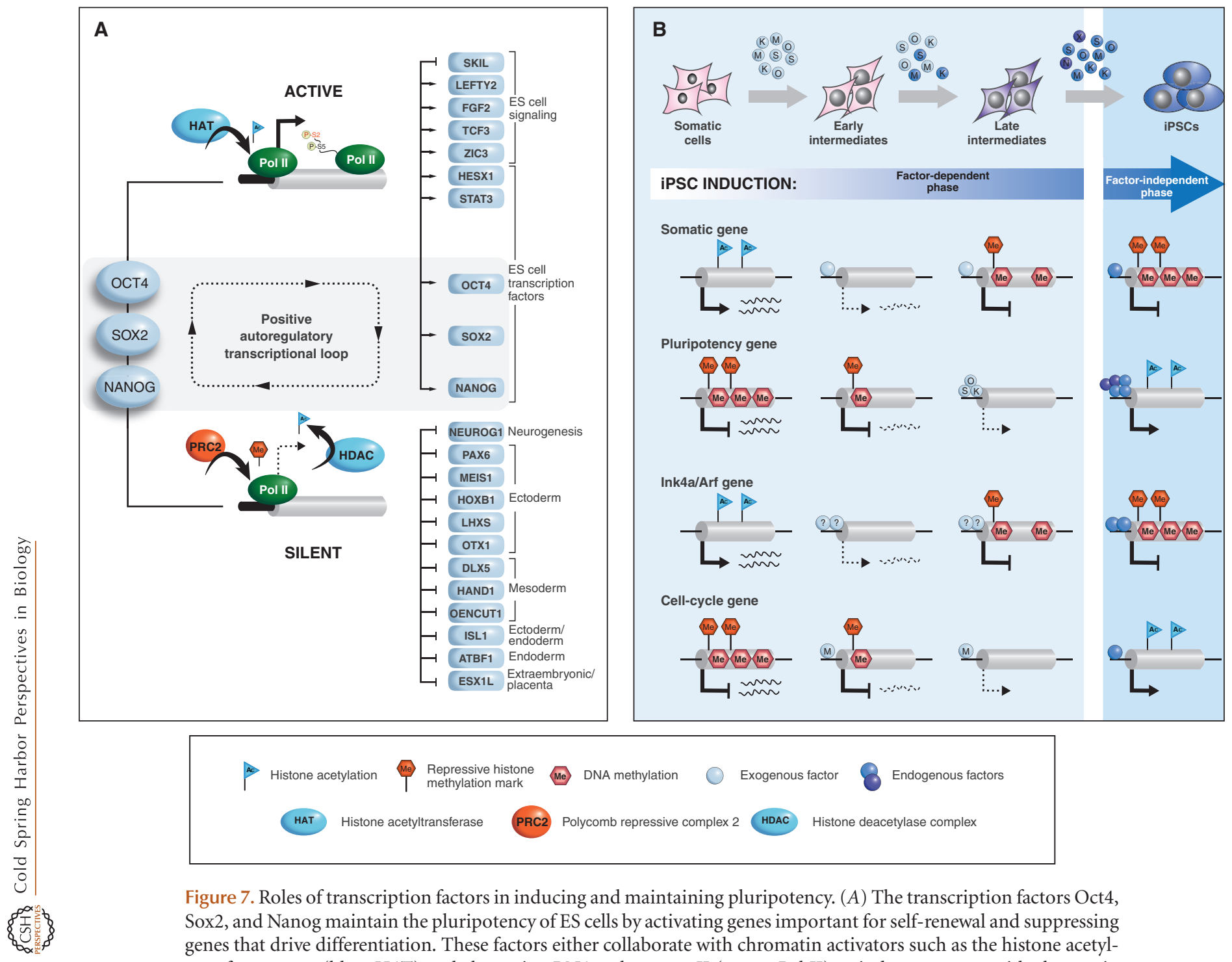

Figure 7. Roles of transcription factors in inducing and maintaining pluripotency. $(A)$ The transcription factors Oct4, Sox2, and Nanog maintain the pluripotency of ES cells by activating genes important for self-renewal and suppressing genes that drive differentiation. These factors either collaborate with chromatin activators such as the histone acetyltransferase p300 (blue, HAT) and elongating RNA polymerase II (green, Pol II) to induce genes or with chromatin repressors such as PRC2 and histone deacetylase complexes (HDAC) to inhibit genes through repressive histone methylation and the removal of histone acetylation. Moreover, pluripotency factors positively regulate their own transcription, thus establishing a transcriptional circuitry typical of ES cells and iPSCs. (B) Model of how reprogramming factors act during iPSC induction. Somatic cells expressing exogenous reprogramming factors transition from "early intermediates" to "late intermediates" to iPSCs (blue circles: O, Oct4; S, Sox2, K, Klf4, M, c-Myc). To acquire pluripotency, cells must activate endogenous pluripotency genes (dark blue circles) as well as essential cofactors (blue circles labeled N, Nanog; X, other factors) to sustain self-renewal in the absence of exogenous factors. (Bottom) Model of how reprogramming factors establish pluripotency in somatic cells via their action at different types of genes. Single factors may suppress somatic genes early, whereas combinations of factors activate pluripotency genes late in reprogramming. Pluripotency is stabilized once suppressive chromatic marks are deposited at somatic genes and removed from silenced pluripotency loci. Successful reprogramming is tightly linked with the acquisition of indefinite self-renewal properties through activation of proliferation genes such as cyclins (mostly targeted by c-Myc) and suppression of cell-cycle inhibitor genes such as Ink4a/Arf by unknown factors. (A, Adapted, with permission, from Jaenisch and Young 2008; B, adapted, with permission, from Stadtfeld and Hochedlinger 2010.) 
maintaining activating histone methylation (Lin et al. 2009) and acetylation (Knoepfler 2008) marks (Fig. 7B). Once Oct4 and Sox2 have activated key pluripotency targets, such as Nanog, cells enter a self-sustaining pluripotent state that is no longer dependent on exogenous factor expression.

It is important to mention that Oct4, Sox2, Klf4, and cMyc are not the only factor combination that can generate iPSCs. For example, human iPSCs have been derived by enforced expression of Oct4, Sox2, Nanog, and Lin28 (Yu et al. 2007). This suggests that different routes may lead to a common pluripotent ground state or, alternatively, that different transcription factors activate the same program by reinforcing each other's synthesis. Indeed, Lin28 represses let-7 microRNAs (Viswanathan et al. 2008), which are negative regulators of c-Myc translation (Kim et al. 2009b), thus establishing a possible link between the two reprogramming cocktails. Likewise, Nanog controls a similar set of target genes as the Klf proteins (Jiang et al. 2008). Hence, cellular reprogramming does not seem to strictly depend on a fixed set of transcription factors, but is rather tolerant of alternative factors as long as the pluripotency circuitry typical of ES cell is established. In further support of this notion, Sox2, Klf4, and c-Myc can be replaced by the closely related Sox1, Klf2, and L-Myc proteins (Nakagawa et al. 2008; Nakagawa et al. 2010). However, some of the classical reprogramming factors are replaceable by seemingly unrelated members of the nuclear orphan receptor family. For instance, Klf4 can be replaced by Esrrb (Feng et al. 2009) and Oct4 by Nr5a2 (Heng et al. 2010) during mouse fibroblast reprogramming. The mechanisms by which these alternative proteins operate during reprogramming remain elusive.

\subsection{Chromosome Inactivation}

$\mathrm{X}$ chromosome inactivation in female mammals ensures balanced gene expression of X-linked genes compared with males (Augui et al. 2011). X inactivation occurs randomly on one of the two female Xs per cell during early postimplantation development and is stably maintained in all somatic daughter cells throughout adulthood. X inactivation is accomplished by a complex interaction of epigenetic mechanisms that involve the noncoding RNA Xist, which coats the future inactive $\mathrm{X}$ and recruits repressive chromatin regulators, resulting in the acquisition of inhibitory histone and DNA methylation marks that induce stable silencing (summarized in Fig. 10 of Brockdorff and Turner 2014). Although all differentiated female cells show $\mathrm{X}$ inactivation, with one active and one inactive $\mathrm{X}$ chromosome (XiXa), mouse ICM cells and derivative ES cells are in a preinactivation state and thus carry two active Xs (XaXa). This observation raised the question of whether induced pluripotency entails faithful reactivation of the somatically silenced X chromosome. Analysis of mouse iPSCs derived from female fibroblasts showed that the silenced X chromosome did indeed become reactivated and undergo random inactivation when cells were induced to differentiate (Maherali et al.2007). This finding is reminiscent of the previous observation that embryos cloned from fibroblasts by SCNT reactivate the silenced $\mathrm{X}$ chromosome and undergo random $\mathrm{X}$ inactivation during development (Eggan et al. 2000).

The state of X inactivation in human ES cells has been puzzling (Wutz 2012). In contrast to mouse ES cells, conventional human $\mathrm{ES}$ cells have undergone $\mathrm{X}$ inactivation (XiXa; Shen et al.2008), raising the question of whether this reflects the X inactivation state of ICM cells in human blastocysts. Two observations support the notion that human ICM cells are in a pre-X inactivation state: (1) Direct observation indicates that cells of human blastocysts have not as yet commenced X inactivation (Okamoto et al. 2011), and (2) human ES cells isolated and propagated under physiological oxygen conditions $\left(5 \% \mathrm{O}_{2}\right)$ displayed a pre-X inactivation status and, similar to mouse ES cells, initiated random inactivation on differentiation (Lengner et al. 2010). The latter observation suggested that suboptimal culture conditions such as oxidative stress may interfere with the in vitro capture of the more immature XaXa state of human ICM cells. More recent data have shown that human ES cells and iPSCs can lose Xist expression and gain biallelic expression of some X-linked genes (Mekhoubad et al. 2012), and that prolonged culture may select for overexpression of growth-promoting X-linked genes (Anguera et al. 2012). These observations are consistent with the possibility that the state of $\mathrm{X}$ inactivation in pluripotent cells may be less stable than in somatic cells and that continuous propagation of the cells may result in cultures with partially reactivated Xi. It is important to note that the state of pluripotency of ES cells and iPSCs has a profound impact on the state of X inactivation as discussed in Section 3.7.

\subsection{Alternative States of Pluripotency: Naïve versus Primed Cells}

Pluripotent cell lines exist in two distinct states that are characterized by different growth factor requirements and developmental properties (Fig. 8). Murine ES cells, established from the ICM of preimplantation blastocysts in the presence of leukemia inhibitory factor (LIF) and BMP, exist in a more primitive pluripotent state in contrast to epiblast stem cells (EpiSCs), derived from the implanted embryo in the presence of bFgf and Activin. Nichols and Smith have designated the ICM-like state of ES cells as the "naïve" state and that of the epiblast-derived EpiSCs as the "primed" pluripotent state (Nichols and Smith 2009). This definition implies that the primed state is prone to differentiation 


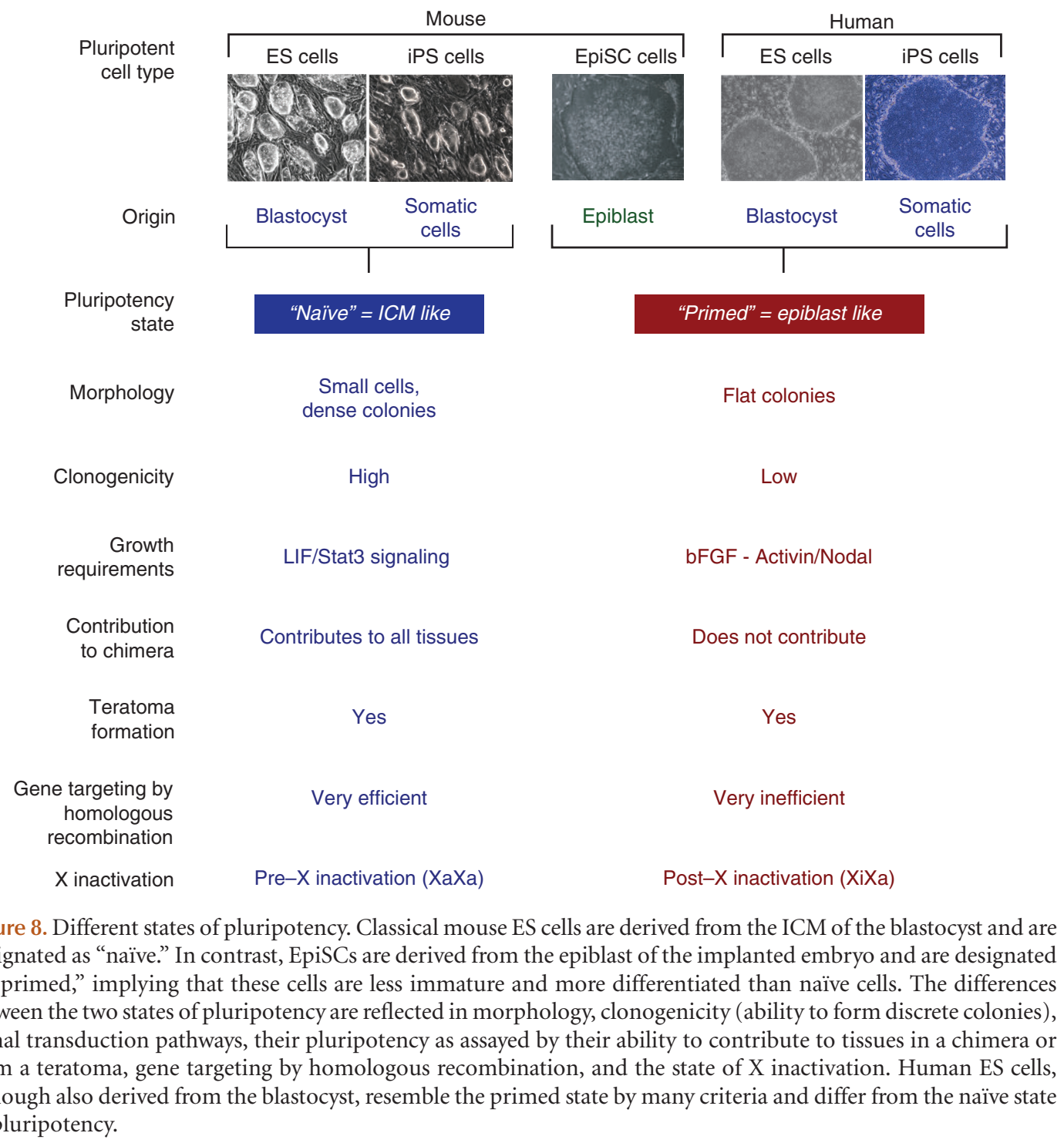

whereas the naïve ES cells correspond to a more immature state of pluripotency. The state of $\mathrm{X}$ inactivation reflects the different states of pluripotency: Naïve female ES cells are in the XaXa preinactivation state, whereas primed EpiSCs have already undergone X-chromosome inactivation (Fig. 8). Consistent with their advanced developmental state, EpiSCs show some pluripotency criteria such as teratoma formation, but fail to contribute to any tissues in chimeric mice (Brons et al. 2007; Tesar et al. 2007). Of interest is that the two alternative states of pluripotency are metastable and can be interconverted by changes in culture conditions; EpiSCs can be reverted to naïve ES cell-like cells on exposure to LIF/Stat3 signaling, and this conversion can be boosted by transient expression of pluripotency factors including Klf4, Klf2, Nanog, or c-Myc, or by cultivation of cells in LIF and " $2 \mathrm{i}$ " conditions (2i: GSK3 $\beta$ inhibitor and ERK1/2 inhibitor or Kenpaullone; Guo et al. 2009; Hanna et al. 2009a). Conversely, exposure to bFGF and Activin converts the naïve ES cells into primed EpiSCs. Thus, activating different signaling pathways through different culture conditions can alter and stabilize the two alternative states of pluripotency.

Human ES cells, like mouse ES cells, are isolated from explanted preimplantation blastocysts by a protocol established by Thomson and colleagues (Thomson et al. 1998). These cells share multiple defining features with mouse EpiSCs rather than mouse ES cells, including a flat morphology, signaling dependence on bFGF/Activin, propensity for X-chromosome inactivation, and reduced tolerance to single cell dissociation (Fig. 8). Thus, these molecular and biological similarities with mouse EpiSCs suggest that human ES cells correspond to the primed pluripotent state 
rather than to the naïve state of mouse ES cells. This raised the question of whether conditions can be devised that allow isolation of human pluripotent cells with defining biological and epigenetic features of mouse naïve ES cells and whether human ES cells or iPSCs, similar to mouse EpiSCs, could be converted to a naïve pluripotent state. Indeed, the propagation of human pluripotent stem cells in LIF/"2i" conditions and overexpression of Oct4 and Klf4 or KLF2/ KLF4 induced conversion of conventional human ES cells to a naïve pluripotent state (Hanna et al. 2010a). The naïve human ES cells and iPSCs resembled naïve mouse ES cells by several criteria: They had reactivated the inactive $\mathrm{X}$ chromosome resulting in a $\mathrm{XaXa}$ pre- $\mathrm{X}$ inactivation status, showed high single-cell cloning efficiency (i.e., high clonogenicity), were dependent on LIF/STAT3 instead of bFGF/ Activin signaling, could routinely be passaged as single cells, and showed a gene expression pattern that more closely resembled that of naïve mouse ES cells. However, the naïve state cannot be robustly maintained and depends on the continuous expression of transgenes. Thus, it is of major interest to define conditions that would allow the maintenance of genetically unmodified naïve cells and to isolate mouse ES-like cells directly from human blastocysts.

\section{APPLICATIONS OF IPSC TECHNOLOGY IN DISEASE RESEARCH}

The most exciting application of iPSC technology is the potential of deriving patient-specific pluripotent cells for disease research. One can distinguish between two different applications of patient-derived iPSCs: (1) studying diseases in tissues culture ("diseases in the dish" approach), and (2) cell transplantation therapy. A crucial requirement to fully realize the potential of iPSCs in disease research is efficient gene-targeting methods in human pluripotent cells. We will first summarize the different approaches to genetically manipulate human ES cells and iPSCs, followed by a discussion of iPSC technology in disease modeling and cell therapy.

\subsection{Genetic Modification of Human ES Cells and iPSCs}

Gene targeting by homologous recombination is efficient in mouse ES cells and has facilitated the generation of thousands of genetically modified mouse models. In contrast, homologous recombination has proven to be difficult in human ES cells and iPSCs, and only few reports have described successful gene targeting since the derivation of the first human ES cells more than 15 years ago. The difficulty of genetic manipulation has been a major obstacle to realizing the full potential of human ES cells and iPSCs in disease research.
Novel tools to facilitate homologous recombination, based on the introduction of DNA double-strand breaks (DSBs) by site-specific nucleases, have been used to target genes in human cells. Two approaches that can introduce site-specific DSBs have been devised: (1) zinc-finger nucleases (ZFNs) (Urnov et al. 2010) and (2) "transcription activator-like effector" (TALE) proteins (Bogdanove and Voytas 2011). In both strategies, DNA-binding domains with new sequence specificities are generated and fused to nucleases that introduce a DSB at a specific nucleotide. A ZFN is generated by fusing the FokI nuclease domain to a DNA recognition domain composed of engineered zincfinger motifs that specify the genomic DNA-binding site for the chimeric protein. On binding of two such fusion proteins at adjacent genomic sites, the nuclease domains dimerize, become active, and cut the genomic DNA (Fig. 9A). When a donor DNA that is homologous to the target on both sides of the DSB is provided, the genomic site can be repaired by homology-directed repair, allowing the incorporation of exogenous sequences placed between the homologous regions. Although zinc-finger domains recognize nucleotide triplets, the DNA-binding domains of TALEs recognize single nucleotides: multiple $\sim 34$-amino-acid units (also referred to as TALE repeats) are arranged in tandem, their sequences being nearly identical except for two highly variable amino acids that establish the base recognition specificity for each unit. Each individual domain determines the specificity of binding to one DNA base pair and, therefore, four different repeat units are sufficient to specify binding to a novel site. As in the ZFN approach, the nuclease fused to the TALE module introduces a specific DSB between the two DNA-binding domains.

The insertion of donor sequences at the DSB is accomplished by cotransfecting the ZFN or TALEN pair together with a donor plasmid designed to carry approximately $500-750$ bp of homologous sequence flanking both sides of the recognition site allowing the generation of reporter ES cells or iPSCs that carry a GFP marker in key transcription factor genes (Hockemeyer et al. 2009, 2011). Gene editing using the ZFN or TALEN strategy has been used to introduce disease-relevant mutations into normal ES cells or correct the mutations in patient-derived iPSCs (Soldner et al. 2011). This creates "isogenic" pairs of disease and control cells (Fig. 9B) that, as outlined below, allow a meaningful comparison between experimental and control cells.

\subsection{Disease Modeling in the Culture Dish ("Disease in the Dish")}

iPSC technology facilitates the generation of genetically identical cells from patients afflicted with a disease of known or unknown etiology. Because the cells are derived 
A

1. Specific pair of ZNF nuclease binds to DNA sequences

2. Attached nuclease creates double-strand break (DSB)
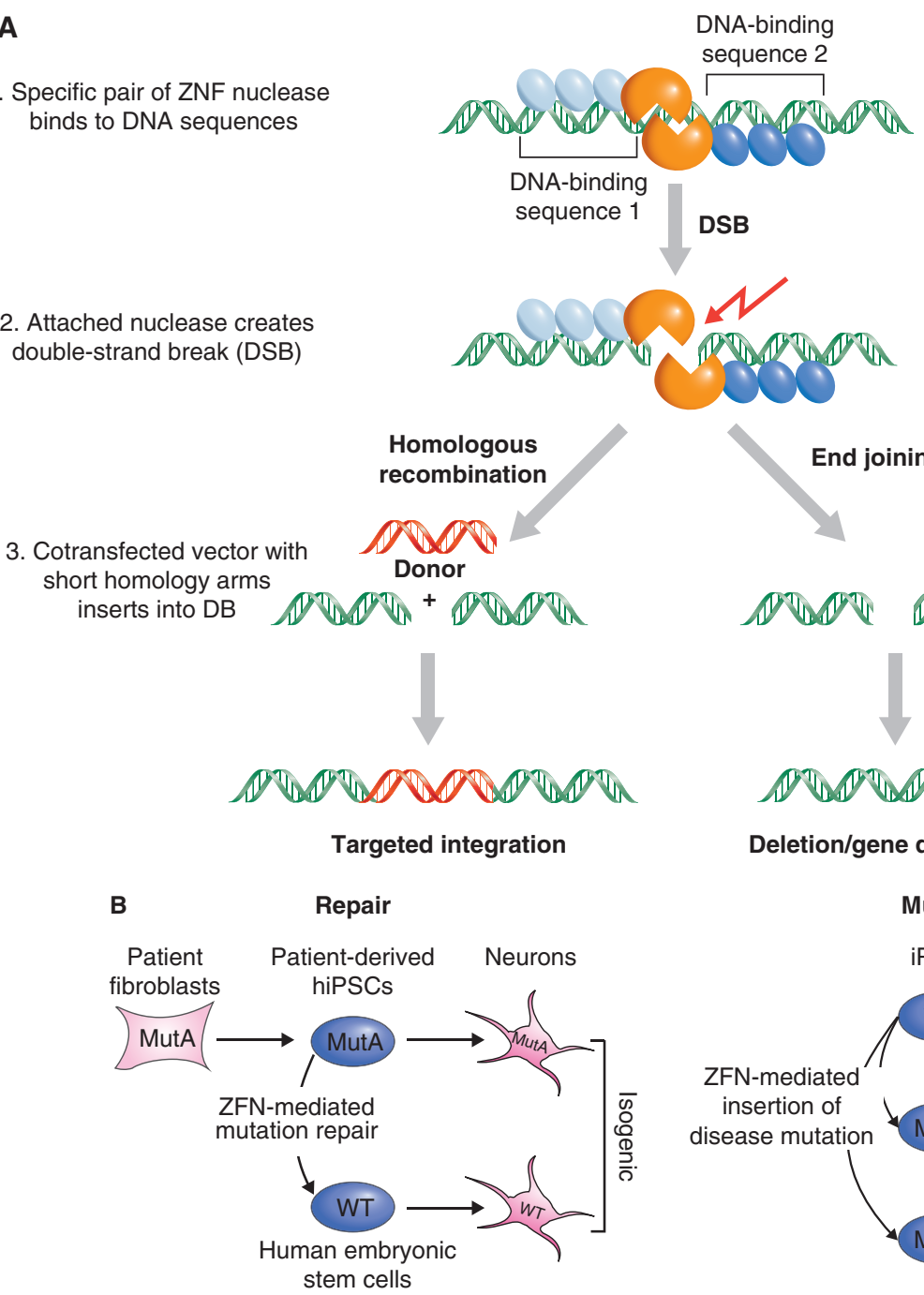

Figure 9. ZFN and TALE nuclease-mediated gene targeting. (A) (1) DNA-binding proteins-either zinc-finger or TALE proteins in blue fused to a Fok1 restriction nuclease in orange-are designed to specifically recognize two adjacent DNA-binding sequences with a defined spacing. (2) On binding of the zinc fingers, the FOK1 nuclease domains dimerize, become active, and cut the DNA. (3) If a donor plasmid carrying DNA (red, DNA) homologous to the DSB is ectopically provided to the cell, this can be used to repair the DNA lesion. A donor plasmid can be designed so that it carries additional sequence in between the homology arms. On repair of the DSB with such a donor, the genomic locus will be altered to carry this additional sequence as an insertion at the site of the DSB. (4) Alternatively, the DSB is repaired, incurring deletion or sequence alteration that disrupts gene function. $(B)$ Using ZFN (or TALEN)-mediated gene targeting, a disease causing mutation is either corrected in a patient-derived iPSC (left illustration), or disease-causing mutations are introduced into wild-type (WT) ES cells (right illustration). The result of either manipulation will be the generation of isogenic sets of iPSCs, providing a genetically matched control for functional studies. (B, Adapted, with permission, from Soldner et al. 2011.)

from the patient, they carry all genetic alterations that may have contributed to the disease manifestation allowing, in principle, the investigation of the genetic basis of the disorder even if the genes that contribute to the disease have not yet been identified.

The basis for modeling diseases in the culture dish is the ability to differentiate iPSCs into the cell type that is affected in the patient (Fig. 10). For example, iPSCs need to be differentiated into dopaminergic neurons to model Parkinson's disease (PD) and they need to be coaxed into motor neurons to study spinal motor atrophy (SMA; depicted in Fig. 11), a fatal disease causing paralysis of the lower body. Importantly, the differentiation of the disease-specific iPSCs into functional somatic cells must show a quantifiable phenotype when compared with proper control cells. In $\mathrm{PD}$, patient-derived dopaminergic neurons can be ana- 


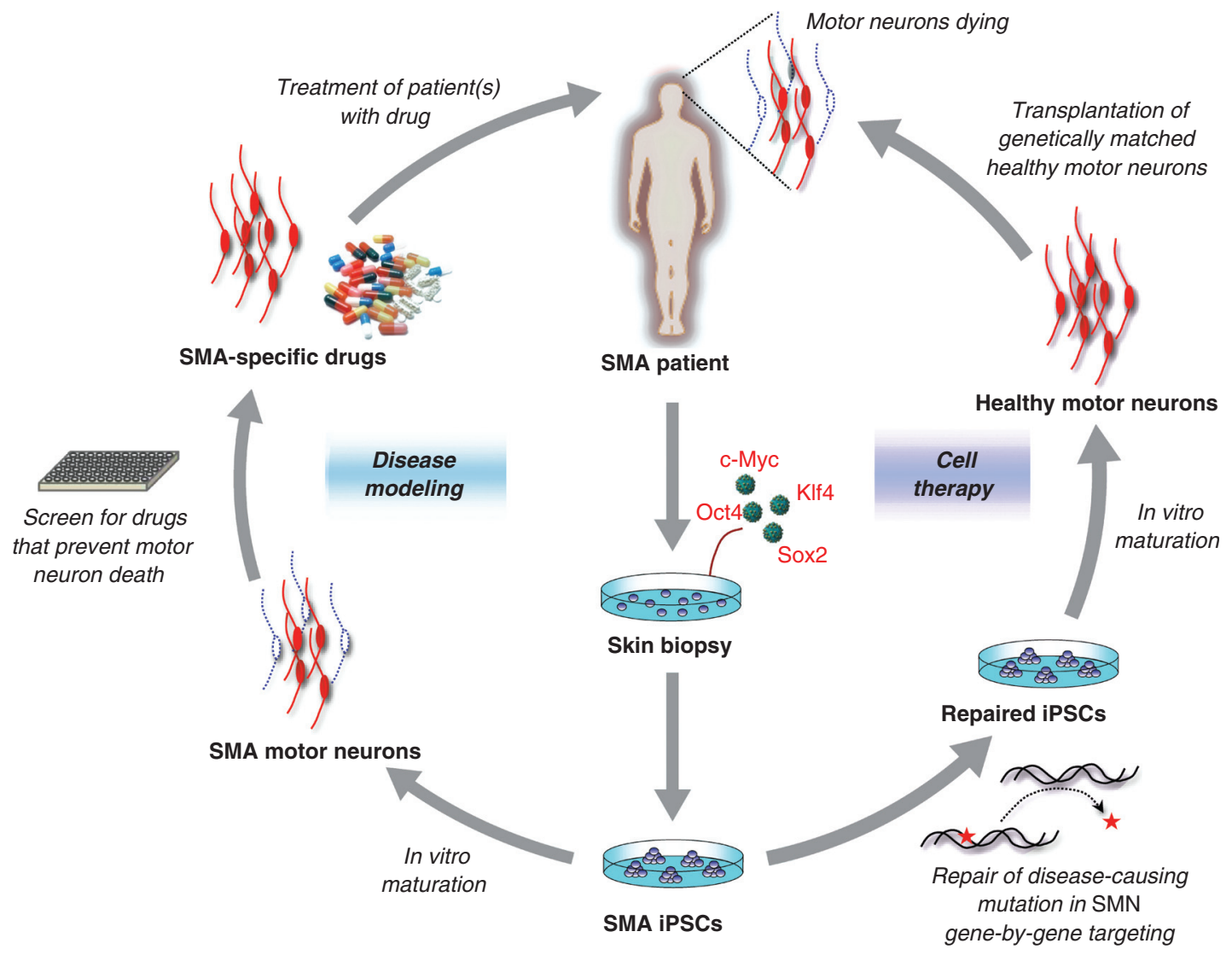

Figure 10. Potential applications of iPSC technology. Shown are the potential applications of iPSC technology for cell therapy and disease modeling using SMA as an example. In SMA patients, motor neurons are afflicted and die causing the devastating symptoms of the disease. SMA-specific iPSCs could be coaxed into motor neurons in vitro to establish a culture model of the disease that may lead to the identification of novel drugs that prevent the abnormal death of motor neurons in patients. Alternatively, the disease-causing mutation could be repaired, if known (in this case, $S M N$ gene), in iPSCs by gene targeting before their differentiation into healthy motor neurons and transplantation into the patient's brain. (Adapted, with permission, from Stadtfeld and Hochedlinger 2010.)

lyzed for phenotypic abnormalities when compared to neurons derived from control iPSCs. Similarly, to study SMA, patient-derived motor neurons can be examined for an in vitro phenotype that may correspond to neuronal defects seen in the patient. An important goal of such experiments is to screen for small molecules that can affect the observed in vitro phenotype (Fig. 10) (Rubin 2008). If such compounds could be identified, they may represent promising candidates for drug development to treat the disease.

How far are we from identifying new drugs with iPSCs? In fact, several research laboratories have already derived iPSCs from patients suffering from Huntington's and Parkinson's disease, ALS, juvenile diabetes, muscular dystrophy, Fanconi anemia, Down syndrome, and others (Raya et al. 2009; Soldner et al. 2009), which will facilitate these studies. Moreover, three promising reports showed that iPSCs derived from patients suffering from the devastating disorders SMA (Ebert et al. 2009), familial dysautonomia
(Lee et al. 2009), and LEOPARD syndrome (Carvajal-Vergara et al. 2010) recapitulated the cell abnormalities in a Petri dish as they are seen in patients. Remarkably, when the cultured cells were exposed to experimental drugs for these diseases, the "symptoms" were partially alleviated in culture. It is noteworthy that neurons differentiated from iPSCs derived from patients suffering from Rett syndrome (Marchetto et al. 2010) or schizophrenia (Brennand et al. 2011) were shown to display a patient-specific phenotype in the culture dish. These observations suggest that iPSC technology may allow studying even such complex mental disorders such as autism (Rett) or psychoses (schizophrenia) on a cellular level. The hope is that this experimental approach can be applied to many other diseases and cell types for which we currently do not have treatments, and this may result in the development of drugs from which not just one individual, as in cell therapy, but millions of patients may benefit. 


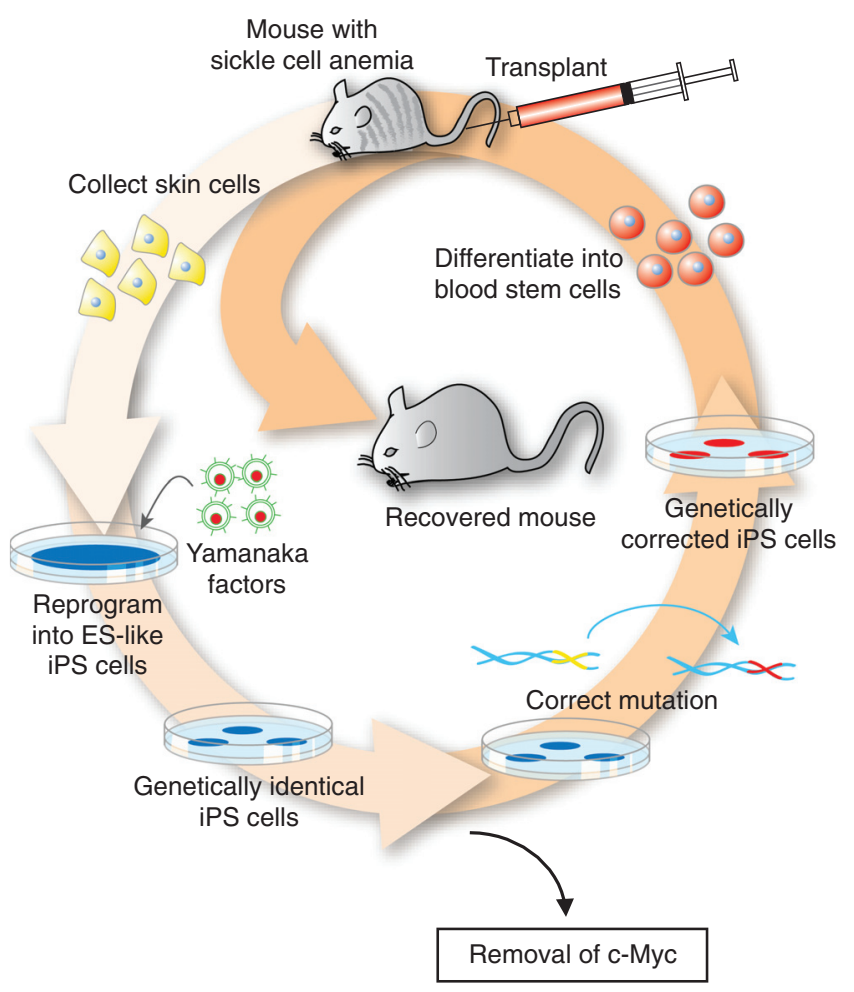

Figure 11. Proof of concept for cell therapy using iPSCs in a humanized model of sickle cell anemia. Transgenic mice carrying the human $\alpha$-globin gene and the anemia-causing $\beta$-globin variant develop disease that resembles human sickle cell anemia. Skin cells were reprogrammed to iPSCs by the four Yamanaka factors and c-Myc was removed by Cre-mediated excision. Homologous recombination was used to correct the mutation in the defective $\beta$-globin gene; the corrected iPSCs were differentiated into hematopoietic stem cells and transplanted into the mutant mice. The cells engrafted and generated normal red blood cells curing the anemia.

\subsection{Cell Therapy}

A widely popularized application of iPSCs is cell replacement therapy. Because iPSCs are genetically matched with the patient donor, this approach eliminates the need for immune-suppressive therapy needed in conventional transplantation settings using cells or organs from unmatched donors (Fig. 10). Indeed, recent experiments have validated this concept using a humanized mouse model of sickle cell anemia (Hanna et al. 2007). Sickle cell anemia is the result of a single-point mutation in the hemoglobin gene, causing red blood cells to adopt a crescent-like shape, which renders them nonfunctional. In this proof-of-concept study, skin cells from the mouse model, which recapitulates the human condition, were first reprogrammed into iPSCs. The disease-causing mutation was subsequently fixed in iPSCs by gene targeting and the repaired cells were then coaxed into blood-forming progenitors (Fig. 11). These now healthy progenitors were transplanted back into anemic mice where they produced normal red blood cells and cured the disease. In principle, this approach could be applied to any disease in humans for which the underlying mutation is known and can be treated by cell transplantation.

However, major challenges need to be overcome before iPSC-based cell therapy can be considered for clinical use (Daley 2012). These include potential tumor (teratoma) formation, the development of robust protocols to derive the cells used for transplantation, and effective delivery of the cells into the patient.

\subsubsection{Teratoma Formation}

A significant safety consideration of using iPSCs for clinical practice is the risk of tumor formation. Undifferentiated ES cells or iPSCs induce teratomas when injected into immune-compromised animals (see Table 2). A teratoma is a complex tumor consisting of undifferentiated embryonic as well as differentiating cell types. Thus, a crucial challenge for any iPSC-based therapy is to eliminate all undifferentiated cells that may be present in the cell preparation used for transplantation.

\subsubsection{Differentiation into Functional Cells}

A major issue of using iPSCs or ES cells for transplantation therapy is the derivation of functional differentiated cells from undifferentiated stem cells. Growing evidence indicates that current differentiation protocols yield mostly immature cells ( $\mathrm{Wu}$ and Hochedlinger 2011). For example, only immature $\beta$ cells of the pancreas have been derived from ES cells, yielding low levels of insulin, which would be insufficient for replacement therapy in type 1 diabetes patients. Also, differentiation into some cell types such as the hematopoietic lineage is extremely inefficient; so far, no hematopoietic stem cells (HSCs) have been generated that have successfully engrafted over the long term in immunecompromised animals. Likewise, it remains unclear whether neuroblasts or mature neurons are the better donor cell population for transplantation therapy of neurodegenerative diseases such as PD. It will, therefore, be of great importance to generate not only mature functional cells but also the committed, self-renewing stem cells from ES cells/ iPSCs as these may be the cells that are most appropriate for cell therapy. Thus, a major challenge for current research is the development of robust protocols that yield homogenous populations of functional cells that could be used for cell replacement therapy.

\subsubsection{Delivery of Cells}

As with gene therapy, delivery of the therapeutic agent is a crucial issue for regenerative medicine. Depending on the 
target tissue, cell delivery can be straightforward or complex. For example, HSCs normally colonize the bone marrow when injected into the circulation, a principle that has been successfully used in the clinic for decades. Thus, if HSCs could be successfully derived from iPSCs, their delivery would pose no problem. Similarly, pancreatic $\beta$ cells derived from cadavers have been shown to regulate glucose levels when transplanted into the livers of type 1 diabetes patients, although long-term survival of the cells was compromised owing to immune rejection. If mature $\beta$ cells could be differentiated from patient-specific iPSCs, they would still be rejected because of the underlying autoimmune disorder inherent to diabetes and would therefore require repeated transplantation. Some applications, such as cell replacement therapy in PD patients, face yet additional challenges because the transplanted cells would need to be placed into a specific brain region by stereotactic injection.

In summary, many hurdles need to be overcome before the iPSC approach can be considered for clinical application (Daley 2012). However, recent progress in tissue engineering is encouraging and suggests that some of these obstacles are of a technical nature and, hence, should be surmountable. For example, epithelial and endothelial cells seeded on scaffolds of decellularized material have produced artificial tissues that can function for a limited time when transplanted into animals (Wu and Hochedlinger 2011). Nevertheless, it should be emphasized that cell transplantation for tissue regeneration will be extremely challenging for diseases such as Alzheimer's, muscular dystrophy, or cystic fibrosis in which a large fraction of dysfunctional cells in complex organs such as brain, skeletal muscle, or lung and intestine would need to be replaced.

\section{AN UNRESOLVED ISSUE: ARE iPSCs EQUIVALENT TO ES CELLS?}

Both iPSCs and ES cells are equivalent based on criteria such as expression of pluripotency markers, in vitro differentiation to various cell types, and in vivo differentiation in the teratoma assay (Fig. 8). However, controversy exists as to whether specific epigenetic or genetic differences distinguish iPSCs from ES cells. A number of studies found that iPSCs showed a higher level of mutations (Gore et al. 2011; Hussein et al. 2011) and different global expression patterns (Chin et al. 2009) when compared with ES cells. It was also discovered that iPSCs displayed "epigenetic memory" of the donor cells; iPSCs derived from fibroblasts, blood, or liver cells had a DNA methylation signature reminiscent of the respective donor cells (Kim et al. 2010; Lister et al. 2011; Ohi et al. 2011). However, these issues remain controversial as more extensive studies comparing large numbers of ES cells and iPSCs failed to find significant expression (Guenther et al. 2010; Newman and Cooper 2010) or epigenetic differences (Bock et al. 2011), arguing that the dissimilarities between ES cells and iPSCs reported in the previous studies were not larger than the variations seen within individual ES cells or iPSCs. Also, it was discovered that mutations found in iPSCs cells preexisted in the donor cells (Cheng et al. 2012; Young et al. 2012) rather than were accrued de novo as a consequence of reprogramming. In addition, methylation changes seen in early-passage iPSCs tended to disappear with continuous culture (Polo et al. 2010), suggesting that such epigenetic differences between ES cells and iPSCs are not stable and may be of little functional consequence.

Nevertheless, much evidence indicates that highly variable biological characteristics such as the propensity to differentiate into specific functional cells exist between ES cells and iPSCs, as well as between individual iPSCs and ES cells (Bock et al. 2011). The basis for these profound differences is manifold and includes differences in genetic background, variegation effects, and residual transgene expression of the viral vectors used to induce reprogramming (Soldner et al. 2009). It has further been shown that parameters associated with the iPSC derivation process, such as the stochiometry of the reprogramming factors (Stadtfeld et al. 2010a; Carey et al. 2011) or the particular medium composition used to culture the cells (Stadtfeld et al. 2012), can profoundly affect the quality of the resultant iPSCs.

For any iPSC-based disease research, the variability between individual iPSC clones in their ability to proliferate or differentiate poses a potentially serious limitation. For example, if a subtle phenotype in the survival of dopaminergic neurons from a PD-derived iPSC line was seen in comparison to cells derived from control iPSCs, the question is whether this phenotype truly reflects a disease-specific abnormality rather than variability between genetically unrelated iPSC lines. The use of ZNF-based gene-targeting approaches to create isogenic pairs of experimental and control iPSCs that differ exclusively at a single-disease relevant mutation offers one approach to overcome this potential problem (Fig. 9B) (Soldner et al. 2011). Any cellular change seen in the patient-derived cells, but not in isogenic controls, would give confidence that the respective phenotype is indeed disease-related and not a consequence of variability between different iPSCs. Thus, for long latency diseases such as PD or Alzheimer's, in which the patient-specific phenotype may only be subtle, the generation of isogenic pairs of disease and control cells may be particularly important. However, it should be emphasized that genetically matched control cells cannot be generated for iPSCs from polygenic diseases. 


\section{CONCLUDING REMARKS}

The generation of iPSCs eight years ago has provided researchers with a unique platform to dissect the mechanisms of cellular reprogramming, which largely remained elusive for the past six decades. Although many questions remain, interesting insights have been gained into the process of reprogramming, such as the finding that cells undergo defined sequential molecular events in an apparently stochastic manner, which are influenced by the choice and number of transcription factors as well as the starting cell type and environmental cues. The ease with which iPSCs can be generated with improved methodology has facilitated the development of chemical and small interfering RNA screens as well as biochemical studies that should further unravel the mechanisms of this process.

The discovery of iPSCs has also influenced our view of normal development; only a few transcription factors are actually needed to potently change cell fate and, hence, mammalian cells must have developed epigenetic mechanisms to efficiently lock in a cell once it has differentiated. These mechanisms are often broken in cancer cells, which show features of stem cells and signs of dedifferentiation (discussed further in Baylin and Jones 2014). Notably, many signaling pathways mutated in cancer cells have recently been shown to affect the formation of iPSCs, indicating remarkable similarities between tumorigenesis and cellular reprogramming.

The isolation of iPSCs has also sparked new interest in interconverting mature cell types directly into each other, which has already led to a number of remarkable examples for pancreatic, cardiac, hepatic, and neural cell types. It is likely that many other direct cell switches will be achieved in the near future. It remains to be tested, however, whether cells generated by direct transdifferentiation as well as in vitro differentiation of iPSCs are functionally equivalent to their in vivo counterparts.

Despite numerous technical advances in the derivation of human iPSCs, relatively little is known about their molecular and functional equivalence with ES cells, which might ultimately affect their potential clinical utility. Addressing these questions will require a careful analysis of the genomic and epigenomic integrity of human iPSCs, as well as the development of novel differentiation protocols and reliable assays to evaluate the functionality of iPSC-derived specialized cells.

\section{ACKNOWLEDGMENTS}

K.H. and R.J. declare that portions of the text and figures have been extracted from previous articles by the authors, which are referenced.

\section{REFERENCES}

* Reference is also in this collection.

Aasen T, Raya A, Barrero MJ, Garreta E, Consiglio A, Gonzalez F, Vassena R, Bilic J, Pekarik V, Tiscornia G, et al. 2008. Efficient and rapid generation of induced pluripotent stem cells from human keratinocytes. Nat Biotechnol 26: 1276-1284.

Ang YS, Tsai SY, Lee DF, Monk J, Su J, Ratnakumar K, Ding J, Ge Y, Darr H, Chang B, et al. 2011. Wdr5 mediates self-renewal and reprogramming via the embryonic stem cell core transcriptional network. Cell 145: $183-197$.

Anguera MC, Sadreyev R, Zhang Z, Szanto A, Payer B, Sheridan SD, Kwok S, Haggarty SJ, Sur M, Alvarez J, et al. 2012. Molecular signatures of human induced pluripotent stem cells highlight sex differences and cancer genes. Cell Stem Cell 11: 75-90.

Aoi T, Yae K, Nakagawa M, Ichisaka T, Okita K, Takahashi K, Chiba T, Yamanaka S. 2008. Generation of pluripotent stem cells from adult mouse liver and stomach cells. Science 321: 699-702.

Augui S, Nora EP, Heard E. 2011. Regulation of X-chromosome inactivation by the X-inactivation centre. Nat Rev Genet 12: 429-442.

Banito A, Rashid ST, Acosta JC, Li S, Pereira CF, Geti I, Pinho S, Silva JC, Azuara V, Walsh M, et al. 2009. Senescence impairs successful reprogramming to pluripotent stem cells. Genes Dev 23: 2134-2139.

* Baylin SB, Jones PA. 2014. Epigenetic determinants of cancer. Cold Spring Harb Perspect Biol doi: 10.1101/cshperspect.a019505.

Blelloch R, Venere M, Yen J, Ramalho-Santos M. 2007. Generation of induced pluripotent stem cells in the absence of drug selection. Cell Stem Cell 1: 245-247.

Bock C, Kiskinis E, Verstappen G, Gu H, Boulting G, Smith ZD, Ziller M, Croft GF, Amoroso MW, Oakley DH, et al. 2011. Reference maps of human ES and iPS cell variation enable high-throughput characterization of pluripotent cell lines. Cell 144: 439-452.

Bogdanove AJ, Voytas DF. 2011. TAL effectors: Customizable proteins for DNA targeting. Science 333: $1843-1846$.

Boland MJ, Hazen JL, Nazor KL, Rodriguez AR, Gifford W, Martin G, Kupriyanov S, Baldwin KK. 2009. Adult mice generated from induced pluripotent stem cells. Nature 461: 91-94.

Boyer LA, Plath K, Zeitlinger J, Brambrink T, Medeiros LA, Lee TI, Levine SS, Wernig M, Tajonar A, Ray MK, et al. 2006. Polycomb complexes repress developmental regulators in murine embryonic stem cells. Nature 441: 349-353.

Brambrink T, Hochedlinger K, Bell G, Jaenisch R. 2006. ES cells derived from cloned and fertilized blastocysts are transcriptionally and functionally indistinguishable. Proc Natl Acad Sci 103: 933-938.

Brambrink T, Foreman R, Welstead GG, Lengner CJ, Wernig M, Suh H, Jaenisch R. 2008. Sequential expression of pluripotency markers during direct reprogramming of mouse somatic cells. Cell Stem Cell 2: $151-159$.

Brennand KJ, Simone A, Jou J, Gelboin-Burkhart C, Tran N, Sangar S, Li Y, Mu Y, Chen G, Yu D, et al. 2011. Modelling schizophrenia using human induced pluripotent stem cells. Nature 473: 221-225.

Briggs R, King TJ. 1952. Transplantation of living nuclei from blastula cells into enucleated frogs' eggs. Proc Natl Acad Sci 38: 455-463.

Briggs R, King TJ. 1957. Changes in the nuclei of differentiating endoderm cells as revealed by nuclear transplantation. J Morphol 100: 269311.

* Brockdorff N, Turner BM. 2014. Dosage compensation in mammals. Cold Spring Harb Perspect Biol doi: 10.1101/cshperspect.a019406.

Brons IG, Smithers LE, Trotter MW, Rugg-Gunn P, Sun B, Chuva de Sousa Lopes SM, Howlett SK, Clarkson A, Ahrlund-Richter L, Pedersen RA, et al. 2007. Derivation of pluripotent epiblast stem cells from mammalian embryos. Nature 448: 191-195.

Bussmann LH, Schubert A, Vu Manh TP, De Andres L, Desbordes SC, Parra M, Zimmermann T, Rapino F, Rodriguez-Ubreva J, Ballestar E, et 
al. 2009. A robust and highly efficient immune cell reprogramming system. Cell Stem Cell 5: 554-566.

Carey BW, Markoulaki S, Beard C, Hanna J, Jaenisch R. 2010. Single-gene transgenic mouse strains for reprogramming adult somatic cells. Nat Methods 7: 56-59.

Carey BW, Markoulaki S, Hanna JH, Faddah DA, Buganim Y, Kim J, Ganz K, Steine EJ, Cassady JP, Creyghton MP, et al. 2011. Reprogramming factor stoichiometry influences the epigenetic state and biological properties of induced pluripotent stem cells. Cell Stem Cell 9: 588598.

Carvajal-Vergara X, Sevilla A, D'Souza SL, Ang YS, Schaniel C, Lee DF, Yang L, Kaplan AD, Adler ED, Rozov R, et al. 2010. Patient-specific induced pluripotent stem-cell-derived models of LEOPARD syndrome. Nature 465: 808-812.

Chambers I, Smith A. 2004. Self-renewal of teratocarcinoma and embryonic stem cells. Oncogene 23: 7150-7160.

Chen J, Liu J, Yang J, Chen Y, Chen J, Ni S, Song H, Zeng L, Ding K, Pei D. 2011. BMPs functionally replace Klf4 and support efficient reprogramming of mouse fibroblasts by Oct4 alone. Cell Res 21: 205-212.

Cheng L, Hansen NF, Zhao L, Du Y, Zou C, Donovan FX, Chou BK, Zhou G, Li S, Dowey SN, et al. 2012. Low incidence of DNA sequence variation in human induced pluripotent stem cells generated by nonintegrating plasmid expression. Cell Stem Cell 10: 337-344.

Chin MH, Mason MJ, Xie W, Volinia S, Singer M, Peterson C, Ambartsumyan G, Aimiuwu O, Richter L, Zhang J, et al. 2009. Induced pluripotent stem cells and embryonic stem cells are distinguished by gene expression signatures. Cell Stem Cell 5: 111-123.

Collado M, Blasco MA, Serrano M. 2007. Cellular senescence in cancer and aging. Cell 130: 223-233.

Daley GQ. 2012. The promise and perils of stem cell therapeutics. Cell Stem Cell 10: 740-749.

Davis RL, Weintraub H, Lassar AB. 1987. Expression of a single transfected cDNA converts fibroblasts to myoblasts. Cell 51: 987-1000.

Ebert AD, Yu J, Rose FF Jr, Mattis VB, Lorson CL, Thomson JA, Svendsen CN. 2009. Induced pluripotent stem cells from a spinal muscular atrophy patient. Nature 457: 277-280.

Eggan K, Akutsu H, Hochedlinger K, Rideout W 3rd, Yanagimachi R, Jaenisch R. 2000. X-chromosome inactivation in cloned mouse embryos. Science 290: 1578-1581.

Eggan K, Akutsu H, Loring J, Jackson-Grusby L, Klemm M, Rideout WM 3rd, Yanagimachi R, Jaenisch R. 2001. Hybrid vigor, fetal overgrowth, and viability of mice derived by nuclear cloning and tetraploid embryo complementation. Proc Natl Acad Sci 98: 6209-6214.

Eggan K, Baldwin K, Tackett M, Osborne J, Gogos J, Chess A, Axel R, Jaenisch R. 2004. Mice cloned from olfactory sensory neurons. Nature 428: $44-49$.

Eminli S, Utikal J, Arnold K, Jaenisch R, Hochedlinger K. 2008. Reprogramming of neural progenitor cells into induced pluripotent stem cells in the absence of exogenous Sox2 expression. Stem Cells 26: 2467-2474.

Eminli S, Foudi A, Stadtfeld M, Maherali N, Ahfeldt T, Mostoslavsky G, Hock H, Hochedlinger K. 2009. Differentiation stage determines potential of hematopoietic cells for reprogramming into induced pluripotent stem cells. Nat Genet 41: 968-976.

Evans MJ, Kaufman MH. 1981. Establishment in culture of pluripotential cells from mouse embryos. Nature 292: 154-156.

Feng B, Jiang J, Kraus P, Ng JH, Heng JC, Chan YS, Yaw LP, Zhang W, Loh YH, Han J, et al. 2009. Reprogramming of fibroblasts into induced pluripotent stem cells with orphan nuclear receptor Esrrb. Nat Cell Biol 11: 197-203.

Fusaki N, Ban H, Nishiyama A, Saeki K, Hasegawa M. 2009. Efficient induction of transgene-free human pluripotent stem cells using a vector based on Sendai virus, an RNA virus that does not integrate into the host genome. Proc Jpn Acad Ser B Phys Biol Sci 85: 348-362.

Gaspar-Maia A, Alajem A, Polesso F, Sridharan R, Mason MJ, Heidersbach A, Ramalho-Santos J, McManus MT, Plath K, Meshorer E, et al.
2009. Chd1 regulates open chromatin and pluripotency of embryonic stem cells. Nature 460: 863-868.

Gore A, Li Z, Fung HL, Young JE, Agarwal S, Antosiewicz-Bourget J, Canto I, Giorgetti A, Israel MA, Kiskinis E, et al. 2011. Somatic coding mutations in human induced pluripotent stem cells. Nature 471: 6367.

Guenther MG, Frampton GM, Soldner F, Hockemeyer D, Mitalipova M, Jaenisch R, Young RA. 2010. Chromatin structure and gene expression programs of human embryonic and induced pluripotent stem cells. Cell Stem Cell 7: 249-257.

Guo G, Yang J, Nichols J, Hall JS, Eyres I, Mansfield W, Smith A. 2009. Klf4 reverts developmentally programmed restriction of ground state pluripotency. Development 136: 1063-1069.

Gurdon J. 1962. The developmental capacity of nuclei taken from intestinal epithelium cells of feeding tadpoles. J Embryol Exp Morphol 10: $622-640$

Hanna J, Wernig M, Markoulaki S, Sun CW, Meissner A, Cassady JP, Beard C, Brambrink T, Wu LC, Townes TM, et al. 2007. Treatment of sickle cell anemia mouse model with iPS cells generated from autologous skin. Science 318: 1920-1923.

Hanna J, Carey BW, Jaenisch R. 2008a. Reprogramming of somatic cell identity. Cold Spring Harb Symp Quant Biol 73: 147-155.

Hanna J, Markoulaki S, Schorderet P, Carey BW, Beard C, Wernig M, Creyghton MP, Steine EJ, Cassady JP, Foreman R, et al. 2008b. Direct reprogramming of terminally differentiated mature B lymphocytes to pluripotency. Cell 133: 250-264.

Hanna J, Markoulaki S, Mitalipova M, Cheng AW, Cassady JP, Staerk J, Carey BW, Lengner CJ, Foreman R, Love J, et al. 2009a. Metastable pluripotent states in NOD-mouse-derived ESCs. Cell Stem Cell 4: $513-524$

Hanna J, Saha K, Pando B, van Zon J, Lengner CJ, Creyghton MP, van Oudenaarden A, Jaenisch R. 2009b. Direct cell reprogramming is a stochastic process amenable to acceleration. Nature 462: 595-601.

Hanna J, Cheng AW, Saha K, Kim J, Lengner CJ, Soldner F, Cassady JP, Muffat J, Carey BW, Jaenisch R. 2010a. Human embryonic stem cells with biological and epigenetic characteristics similar to those of mouse ESCs. Proc Natl Acad Sci 107: 9222-9227.

Hanna JH, Saha K, Jaenisch R. 2010b. Pluripotency and cellular reprogramming: Facts, hypotheses, unresolved issues. Cell 143: 508-525.

Heng JC, Feng B, Han J, Jiang J, Kraus P, Ng JH, Orlov YL, Huss M, Yang $\mathrm{L}$, Lufkin T, et al. 2010. The nuclear receptor $\mathrm{Nr} 5 \mathrm{a} 2$ can replace Oct 4 in the reprogramming of murine somatic cells to pluripotent cells. Cell Stem Cell 6: 167-174.

Hochedlinger K, Jaenisch R. 2002. Monoclonal mice generated by nuclear transfer from mature B and T donor cells. Nature 415: 10351038 .

Hochedlinger K, Jaenisch R. 2003. Nuclear transplantation, embryonic stem cells, and the potential for cell therapy. N Engl J Med 5: S114S117.

Hockemeyer D, Soldner F, Cook EG, Gao Q, Mitalipova M, Jaenisch R. 2008. A drug-inducible system for direct reprogramming of human somatic cells to pluripotency. Cell Stem Cell 3: 346-353.

Hockemeyer D, Soldner F, Beard C, Gao Q, Mitalipova M, DeKelver RC, Katibah GE, Amora R, Boydston EA, Zeitler B, et al. 2009. Efficient targeting of expressed and silent genes in human ESCs and iPSCs using zinc-finger nucleases. Nat Biotechnol 27: 851-857.

Hockemeyer D, Wang H, Kiani S, Lai CS, Gao Q, Cassady JP, Cost GJ, Zhang L, Santiago Y, Miller JC, et al. 2011. Genetic engineering of human pluripotent cells using TALE nucleases. Nat Biotechnol 29: 731-734.

Hong H, Takahashi K, Ichisaka T, Aoi T, Kanagawa O, Nakagawa M, Okita K, Yamanaka S. 2009. Suppression of induced pluripotent stem cell generation by the p53-p21 pathway. Nature 460: 1132-1135.

Hou P, Li Y, Zhang X, Liu C, Guan J, Li H, Zhao T, Ye J, Yang W, Liu K, et al. 2013. Pluripotent stem cells induced from mouse somatic cells by small-molecule compounds. Science 341: 651-654. 
Huang P, He Z, Ji S, Sun H, Xiang D, Liu C, Hu Y, Wang X, Hui L. 2011. Induction of functional hepatocyte-like cells from mouse fibroblasts by defined factors. Nature 475: 386-389.

Huangfu D, Maehr R, Guo W, Eijkelenboom A, Snitow M, Chen AE, Melton DA. 2008. Induction of pluripotent stem cells by defined factors is greatly improved by small-molecule compounds. Nat Biotechnol 26: 795-797.

Hussein SM, Batada NN, Vuoristo S, Ching RW, Autio R, Narva E, Ng S, Sourour M, Hamalainen R, Olsson C, et al. 2011. Copy number variation and selection during reprogramming to pluripotency. Nature 471: $58-62$.

Ichida JK, Blanchard J, Lam K, Son EY, Chung JE, Egli D, Loh KM, Carter AC, Di Giorgio FP, Koszka K, et al. 2009. A small-molecule inhibitor of tgf- $\beta$ signaling replaces sox 2 in reprogramming by inducing nanog. Cell Stem Cell 5: 491-503.

Ieda M, Fu JD, Delgado-Olguin P, Vedantham V, Hayashi Y, Bruneau BG, Srivastava D. 2010. Direct reprogramming of fibroblasts into functional cardiomyocytes by defined factors. Cell 142: 375-386.

Inoue K, Wakao H, Ogonuki N, Miki H, Seino K, Nambu-Wakao R, Noda S, Miyoshi H, Koseki H, Taniguchi M, et al. 2005. Generation of cloned mice by direct nuclear transfer from natural killer $\mathrm{T}$ cells. Curr Biol 15: 1114-1118.

Jaenisch R, Gurdon J. 2007. Nuclear transplantation and the reprogramming of the genome. In Epigenetics (ed. Allis CD, et al.), pp. 415-434. Cold Spring Harbor Laboratory Press, Cold Spring Harbor, NY.

Jaenisch R, Young R. 2008. Stem cells, the molecular circuitry of pluripotency and nuclear reprogramming. Cell 132: 567-582.

Jiang J, Chan YS, Loh YH, Cai J, Tong GQ, Lim CA, Robson P, Zhong S, $\mathrm{Ng}$ HH. 2008. A core Klf circuitry regulates self-renewal of embryonic stem cells. Nat Cell Biol 10: 353-360.

Kaji K, Caballero IM, MacLeod R, Nichols J, Wilson VA, Hendrich B. 2006. The NuRD component Mbd3 is required for pluripotency of embryonic stem cells. Nat Cell Biol 8: 285-292.

Kang L, Wang J, Zhang Y, Kou Z, Gao S. 2009. iPS cells can support fullterm development of tetraploid blastocyst-complemented embryos. Cell Stem Cell 5: 135-138.

Kawamura T, Suzuki J, Wang YV, Menendez S, Morera LB, Raya A, Wahl GM, Izpisua Belmonte JC. 2009. Linking the p53 tumour suppressor pathway to somatic cell reprogramming. Nature 460: 1140-1144.

Kelly SJ. 1977. Studies of the developmental potential of 4- and 8-cell stage mouse blastomeres. J Exp Zool 200: 365-376.

Kim JB, Zaehres H, Wu G, Gentile L, Ko K, Sebastiano V, Arauzo-Bravo MJ, Ruau D, Han DW, Zenke M, et al. 2008. Pluripotent stem cells induced from adult neural stem cells by reprogramming with two factors. Nature 454: 646-650.

Kim D, Kim CH, Moon JI, Chung YG, Chang MY, Han BS, Ko S, Yang E, Cha KY, Lanza R, et al. 2009a. Generation of human induced pluripotent stem cells by direct delivery of reprogramming proteins. Cell Stem Cell 4: 472-476.

Kim HH, Kuwano Y, Srikantan S, Lee EK, Martindale JL, Gorospe M. 2009b. HuR recruits let-7/RISC to repress c-Myc expression. Genes Dev 23: $1743-1748$.

Kim K, Doi A, Wen B, Ng K, Zhao R, Cahan P, Kim J, Aryee MJ, Ji H, Ehrlich LI, et al. 2010. Epigenetic memory in induced pluripotent stem cells. Nature 467: 285-290.

Kleinsmith LJ, Pierce GB Jr. 1964. Multipotentiality of single embryonal carcinoma cells. Cancer Res 24: 1544-1551.

Knoepfler PS. 2008. Why myc? An unexpected ingredient in the stem cell cocktail. Cell Stem Cell 2: 18-21.

Laiosa CV, Stadtfeld M, Xie H, de Andres-Aguayo L, Graf T. 2006. Reprogramming of committed $\mathrm{T}$ cell progenitors to macrophages and dendritic cells by $\mathrm{C} / \mathrm{EBP} \alpha$ and PU.1 transcription factors. Immunity 25: $731-744$

Lee TI, Jenner RG, Boyer LA, Guenther MG, Levine SS, Kumar RM, Chevalier B, Johnstone SE, Cole MF, Isono K, et al. 2006. Control of developmental regulators by Polycomb in human embryonic stem cells. Cell 125: $301-313$
Lee G, Papapetrou EP, Kim H, Chambers SM, Tomishima MJ, Fasano CA, Ganat YM, Menon J, Shimizu F, Viale A, et al. 2009. Modelling pathogenesis and treatment of familial dysautonomia using patient-specific iPSCs. Nature 461: 402-406.

Lei H, Oh SP, Okano M, Juttermann R, Goss KA, Jaenisch R, Li E. 1996. De novo DNA cytosine methyltransferase activities in mouse embryonic stem cells. Development 122: 3195-3205.

Lengner CJ, Gimelbrant AA, Erwin JA, Cheng AW, Guenther MG, Welstead GG, Alagappan R, Frampton GM, Xu P, Muffat J, et al. 2010. Derivation of pre-X inactivation human embryonic stem cells under physiological oxygen concentrations. Cell 141: 872-883.

Li E, Bestor TH, Jaenisch R. 1992. Targeted mutation of the DNA methyltransferase gene results in embryonic lethality. Cell 69: 915-926.

Li H, Collado M, Villasante A, Strati K, Ortega S, Canamero M, Blasco MA, Serrano M. 2009a. The Ink4/Arf locus is a barrier for iPS cell reprogramming. Nature 460: 1136-1139.

Li W, Wei W, Zhu S, Zhu J, Shi Y, Lin T, Hao E, Hayek A, Deng H, Ding S. 2009b. Generation of rat and human induced pluripotent stem cells by combining genetic reprogramming and chemical inhibitors. Cell Stem Cell 4: $16-19$.

Li R, Liang J, Ni S, Zhou T, Qing X, Li H, He W, Chen J, Li F, Zhuang Q, et al. 2010. A mesenchymal-to-epithelial transition initiates and is required for the nuclear reprogramming of mouse fibroblasts. Cell Stem Cell 7: 51-63.

Lin CH, Lin C, Tanaka H, Fero ML, Eisenman RN. 2009. Gene regulation and epigenetic remodeling in murine embryonic stem cells by c-Myc. Plos One 4: e7839.

Lister R, Pelizzola M, Kida YS, Hawkins RD, Nery JR, Hon G, Antosiewicz-Bourget J, O’Malley R, Castanon R, Klugman S, et al. 2011. Hotspots of aberrant epigenomic reprogramming in human induced pluripotent stem cells. Nature 471: 68-73.

Liu H, Zhu F, Yong J, Zhang P, Hou P, Li H, Jiang W, Cai J, Liu M, Cui K, et al. 2008. Generation of induced pluripotent stem cells from adult rhesus monkey fibroblasts. Cell Stem Cell 3: 587-590.

Lyssiotis CA, Foreman RK, Staerk J, Garcia M, Mathur D, Markoulaki S, Hanna J, Lairson LL, Charette BD, Bouchez LC, et al. 2009. Reprogramming of murine fibroblasts to induced pluripotent stem cells with chemical complementation of Klf4. Proc Natl Acad Sci 106: 8912-8917.

Maekawa M, Yamaguchi K, Nakamura T, Shibukawa R, Kodanaka I, Ichisaka T, Kawamura Y, Mochizuki H, Goshima N, Yamanaka S. 2011. Direct reprogramming of somatic cells is promoted by maternal transcription factor Glis1. Nature 474: 225-229.

Maherali N, Sridharan R, Xie W, Utikal J, Eminli S, Arnold K, Stadtfeld M, Yachechko R, Tchieu J, Jaenisch R, et al. 2007. Directly reprogrammed fibroblasts show global epigenetic remodeling and widespread tissue contribution. Cell Stem Cell 1: 55-70.

Maherali N, Ahfeldt T, Rigamonti A, Utikal J, Cowan C, Hochedlinger K. 2008. A high-efficiency system for the generation and study of human induced pluripotent stem cells. Cell Stem Cell 3: 340-345.

Mansour AA, Gafni O, Weinberger L, Zviran A, Ayyash M, Rais Y, Krupalnik V, Zerbib M, Amann-Zalcenstein D, Maza I, et al. 2012. The H3K27 demethylase Utx regulates somatic and germ cell epigenetic reprogramming. Nature 488: 409-413.

Marchetto MC, Carromeu C, Acab A, Yu D, Yeo GW, Mu Y, Chen G, Gage FH, Muotri AR. 2010. A model for neural development and treatment of Rett syndrome using human induced pluripotent stem cells. Cell 143: 527-539.

Marion RM, Strati K, Li H, Tejera A, Schoeftner S, Ortega S, Serrano M, Blasco MA. 2009. Telomeres acquire embryonic stem cell characteristics in induced pluripotent stem cells. Cell Stem Cell 4: 141-154.

Markoulaki S, Hanna J, Beard C, Carey BW, Cheng AW, Lengner CJ, Dausman JA, Fu D, Gao Q, Wu S, et al. 2009. Transgenic mice with defined combinations of drug-inducible reprogramming factors. Nat Biotechnol 27: 169-171.

Martin GR. 1981. Isolation of a pluripotent cell line from early mouse embryos cultured in medium conditioned by teratocarcinoma stem cells. Proc Natl Acad Sci 78: 7634-7638. 
Matsui T, Leung D, Miyashita H, Maksakova IA, Miyachi H, Kimura H, Tachibana M, Lorincz MC, Shinkai Y. 2010. Proviral silencing in embryonic stem cells requires the histone methyltransferase ESET. Nature 464: 927-931.

Meissner A, Jaenisch R. 2006. Mammalian nuclear transfer. Dev Dyn 235: $2460-2469$.

Meissner A, Wernig M, Jaenisch R. 2007. Direct reprogramming of genetically unmodified fibroblasts into pluripotent stem cells. Nat Biotechnol 25: 1177-1181.

Mekhoubad S, Bock C, de Boer AS, Kiskinis E, Meissner A, Eggan K. 2012. Erosion of dosage compensation impacts human iPSC disease modeling. Cell Stem Cell 10: 595-609.

Mikkelsen TS, Hanna J, Zhang X, Ku M, Wernig M, Schorderet P, Bernstein BE, Jaenisch R, Lander ES, Meissner A. 2008. Dissecting direct reprogramming through integrative genomic analysis. Nature 454: $49-55$.

Miller RA, Ruddle FH. 1976. Pluripotent teratocarcinoma-thymus somatic cell hybrids. Cell 9: 45-55.

Munsie MJ, Michalska AE, O’Brien CM, Trounson AO, Pera MF, Mountford PS. 2000. Isolation of pluripotent embryonic stem cells from reprogrammed adult mouse somatic cell nuclei. Curr Biol 10: 989992.

Nagy A, Gocza E, Diaz EM, Prideaux VR, Ivanyi E, Markkula M, Rossant J. 1990. Embryonic stem cells alone are able to support fetal development in the mouse. Development 110: 815-821.

Nakagawa M, Koyanagi M, Tanabe K, Takahashi K, Ichisaka T, Aoi T, Okita K, Mochiduki Y, Takizawa N, Yamanaka S. 2008. Generation of induced pluripotent stem cells without Myc from mouse and human fibroblasts. Nat Biotechnol 26: 101-106.

Nakagawa M, Takizawa N, Narita M, Ichisaka T, Yamanaka S. 2010. Promotion of direct reprogramming by transformation-deficient Myc. Proc Natl Acad Sci 107: 14152-14157.

Nemajerova A, Kim SY, Petrenko O, Moll UM. 2012. Two-factor reprogramming of somatic cells to pluripotent stem cells reveals partial functional redundancy of Sox2 and Klf4. Cell Death Differ 19: $1268-1276$.

Newman AM, Cooper JB. 2010. Lab-specific gene expression signatures in pluripotent stem cells. Cell Stem Cell 7: 258-262.

Nichols J, Smith A. 2009. Naive and primed pluripotent states. Cell Stem Cell 4: 487-492.

Ohi Y, Qin H, Hong C, Blouin L, Polo JM, Guo T, Qi Z, Downey SL, Manos PD, Rossi DJ, et al. 2011. Incomplete DNA methylation underlies a transcriptional memory of somatic cells in human iPS cells. Nat Cell Biol 13: 541-549.

Okamoto I, Patrat C, Thepot D, Peynot N, Fauque P, Daniel N, Diabangouaya P, Wolf JP, Renard JP, Duranthon V, et al. 2011. Eutherian mammals use diverse strategies to initiate $\mathrm{X}$-chromosome inactivation during development. Nature 472: 370-374.

Okita K, Ichisaka T, Yamanaka S. 2007. Generation of germline-competent induced pluripotent stem cells. Nature 448: 313-317.

Okita K, Nakagawa M, Hyenjong H, Ichisaka T, Yamanaka S. 2008. Generation of mouse induced pluripotent stem cells without viral vectors. Science 322: 949-953.

Orkin SH, Hochedlinger K. 2011. Chromatin connections to pluripotency and cellular reprogramming. Cell 145: 835-850.

Park IH, Zhao R, West JA, Yabuuchi A, Huo H, Ince TA, Lerou PH, Lensch MW, Daley GQ. 2008. Reprogramming of human somatic cells to pluripotency with defined factors. Nature 451: 141-146.

Pawlak M, Jaenisch R. 2011. De novo DNA methylation by Dnmt3a and Dnmt3b is dispensable for nuclear reprogramming of somatic cells to a pluripotent state. Genes Dev 25: 1035-1040.

Polo JM, Liu S, Figueroa ME, Kulalert W, Eminli S, Tan KY, Apostolou E, Stadtfeld M, Li Y, Shioda T, et al. 2010. Cell type of origin influences the molecular and functional properties of mouse induced pluripotent stem cells. Nat Biotechnol 28: 848-855.

Raya A, Rodriguez-Piza I, Guenechea G, Vassena R, Navarro S, Barrero MJ, Consiglio A, Castella M, Rio P, Sleep E, et al. 2009. Disease-cor- rected haematopoietic progenitors from Fanconi anaemia induced pluripotent stem cells. Nature 460: 53-59.

Reik W, Dean W, Walter J. 2001. Epigenetic reprogramming in mammalian development. Science 293: 1089-1093.

Rubin LL. 2008. Stem cells and drug discovery: The beginning of a new era? Cell 132: 549-552.

Samavarchi-Tehrani P, Golipour A, David L, Sung HK, Beyer TA, Datti A, Woltjen K, Nagy A, Wrana JL. 2010. Functional genomics reveals a BMP-driven mesenchymal-to-epithelial transition in the initiation of somatic cell reprogramming. Cell Stem Cell 7: 64-77.

Shen Y, Matsuno Y, Fouse SD, Rao N, Root S, Xu R, Pellegrini M, Riggs AD, Fan G. 2008. X-inactivation in female human embryonic stem cells is in a nonrandom pattern and prone to epigenetic alterations. Proc Natl Acad Sci 105: 4709-4714.

Singhal N, Graumann J, Wu G, Arauzo-Bravo MJ, Han DW, Greber B, Gentile L, Mann M, Scholer HR. 2010. Chromatin-remodeling components of the BAF complex facilitate reprogramming. Cell 141: $943-$ 955.

Smith ZD, Nachman I, Regev A, Meissner A. 2010. Dynamic single-cell imaging of direct reprogramming reveals an early specifying event. Nat Biotechnol 28: 521-526.

Soldner F, Hockemeyer D, Beard C, Gao Q, Bell GW, Cook EG, Hargus G, Blak A, Cooper O, Mitalipova M, et al. 2009. Parkinson's disease patient-derived induced pluripotent stem cells free of viral reprogramming factors. Cell 136: 964-977.

Soldner F, Laganiere J, Cheng AW, Hockemeyer D, Gao Q, Alagappan R, Khurana V, Golbe LI, Myers RH, Lindquist S, et al. 2011. Generation of isogenic pluripotent stem cells differing exclusively at two early onset Parkinson point mutations. Cell 146: 318-331.

Sridharan R, Tchieu J, Mason MJ, Yachechko R, Kuoy E, Horvath S, Zhou Q, Plath K. 2009. Role of the murine reprogramming factors in the induction of pluripotency. Cell 136: 364-377.

Stadtfeld M, Hochedlinger K. 2010. Induced pluripotency: History, mechanisms, and applications. Genes Dev 24: 2239-2263.

Stadtfeld M, Brennand K, Hochedlinger K. 2008a. Reprogramming of pancreatic $\beta$ cells into induced pluripotent stem cells. Curr Biol 18: 890-894.

Stadtfeld M, Maherali N, Breault DT, Hochedlinger K. 2008b. Defining molecular cornerstones during fibroblast to iPS cell reprogramming in mouse. Cell Stem Cell 2: 230-240.

Stadtfeld M, Nagaya M, Utikal J, Weir G, Hochedlinger K. 2008c. Induced pluripotent stem cells generated without viral integration. Science 322: 945-949.

Stadtfeld M, Apostolou E, Akutsu H, Fukuda A, Follett P, Natesan S, Kono T, Shioda T, Hochedlinger K. 2010a. Aberrant silencing of imprinted genes on chromosome $12 \mathrm{qF} 1$ in mouse induced pluripotent stem cells. Nature 465: 175-181.

Stadtfeld M, Maherali N, Borkent M, Hochedlinger K. 2010b. A reprogrammable mouse strain from gene-targeted embryonic stem cells. Nat Methods 7: 53-55.

Stadtfeld M, Apostolou E, Ferrari F, Choi J, Walsh RM, Chen T, Ooi SS, Kim SY, Bestor TH, Shioda T, et al. 2012. Ascorbic acid prevents loss of Dlk1-Dio3 imprinting and facilitates generation of all-iPS cell mice from terminally differentiated B cells. Nat Genet 44: 398-405, S391S392.

Tachibana M, Amato P, Sparman M, Gutierrez NM, Tippner-Hedges R, Ma H, Kang E, Fulati A, Lee HS, Sritanaudomchai H, et al. 2013. Human embryonic stem cells derived by somatic cell nuclear transfer. Cell 153: $1228-1238$.

Tada M, Morizane A, Kimura H, Kawasaki H, Ainscough JF, Sasai Y, Nakatsuji N, Tada T. 2003. Pluripotency of reprogrammed somatic genomes in embryonic stem hybrid cells. Dev Dyn 227: 504-510.

* Takahashi K. 2014. Cellular reprogramming. Cold Spring Harb Persp Biol 6: a018606.

Takahashi K, Yamanaka S. 2006. Induction of pluripotent stem cells from mouse embryonic and adult fibroblast cultures by defined factors. Cell 126: $663-676$. 
Takahashi K, Tanabe K, Ohnuki M, Narita M, Ichisaka T, Tomoda K, Yamanaka S. 2007. Induction of pluripotent stem cells from adult human fibroblasts by defined factors. Cell 131: 861-872.

Tesar PJ, Chenoweth JG, Brook FA, Davies TJ, Evans EP, Mack DL, Gardner RL, McKay RD. 2007. New cell lines from mouse epiblast share defining features with human embryonic stem cells. Nature 448: 196-199.

Thomson JA, Itskovitz-Eldor J, Shapiro SS, Waknitz MA, Swiergiel JJ, Marshall VS, Jones JM. 1998. Embryonic stem cell lines derived from human blastocysts. Science 282: 1145-1147.

Urnov FD, Rebar EJ, Holmes MC, Zhang HS, Gregory PD. 2010. Genome editing with engineered zinc finger nucleases. Nat Rev Genet 11: 636646.

Utikal J, Maherali N, Kulalert W, Hochedlinger K. 2009a. Sox2 is dispensable for the reprogramming of melanocytes and melanoma cells into induced pluripotent stem cells. J Cell Sci 122: 3502-3510.

Utikal J, Polo JM, Stadtfeld M, Maherali N, Kulalert W, Walsh RM, Khalil A, Rheinwald JG, Hochedlinger K. 2009b. Immortalization eliminates a roadblock during cellular reprogramming into iPS cells. Nature $\mathbf{4 6 0}$ $1145-1148$.

Vierbuchen T, Ostermeier A, Pang ZP, Kokubu Y, Sudhof TC, Wernig M. 2010. Direct conversion of fibroblasts to functional neurons by defined factors. Nature 463: 1035-1041.

Viswanathan SR, Daley GQ, Gregory RI. 2008. Selective blockade of microRNA processing by Lin28. Science 320: 97-100.

Wakayama T, Tabar V, Rodriguez I, Perry AC, Studer L, Mombaerts P. 2001. Differentiation of embryonic stem cell lines generated from adult somatic cells by nuclear transfer. Science 292: 740-743.

Wakayama S, Jakt ML, Suzuki M, Araki R, Hikichi T, Kishigami S, Ohta H, Van Thuan N, Mizutani E, Sakaide Y, et al. 2006. Equivalency of nuclear transfer-derived embryonic stem cells to those derived from fertilized mouse blastocysts. Stem Cells 24: 2023-2033.

Wang J, Rao S, Chu J, Shen X, Levasseur DN, Theunissen TW, Orkin SH. 2006. A protein interaction network for pluripotency of embryonic stem cells. Nature 444: 364-368.

Warren L, Manos PD, Ahfeldt T, Loh YH, Li H, Lau F, Ebina W, Mandal PK, Smith ZD, Meissner A, et al. 2010. Highly efficient reprogramming to pluripotency and directed differentiation of human cells with synthetic modified mRNA. Cell Stem Cell 7: 618-630.

Wernig M, Meissner A, Foreman R, Brambrink T, Ku M, Hochedlinger K, Bernstein BE, Jaenisch R. 2007. In vitro reprogramming of fibroblasts into a pluripotent ES-cell-like state. Nature 448: 318-324.
Wernig M, Lengner CJ, Hanna J, Lodato MA, Steine E, Foreman R, Staerk J, Markoulaki S, Jaenisch R. 2008. A drug-inducible transgenic system for direct reprogramming of multiple somatic cell types. Nat Biotechnol 26: $916-924$.

Wilmut I, Schnieke AE, McWhir J, Kind AJ, Campbell KH. 1997. Viable offspring derived from fetal and adult mammalian cells. Nature 385: 810-813.

Woltjen K, Michael IP, Mohseni P, Desai R, Mileikovsky M, Hamalainen R, Cowling R, Wang W, Liu P, Gertsenstein M, et al. 2009. piggyBac transposition reprograms fibroblasts to induced pluripotent stem cells. Nature 458: 766-770.

Wu SM, Hochedlinger K. 2011. Harnessing the potential of induced pluripotent stem cells for regenerative medicine. Nat Cell Biol 13: 497-505.

Wutz A. 2012. Epigenetic alterations in human pluripotent stem cells: A tale of two cultures. Cell Stem Cell 11: 9-15.

Xie H, Ye M, Feng R, Graf T. 2004. Stepwise reprogramming of B cells into macrophages. Cell 117: 663-676.

Xu Y, Shi Y, Ding S. 2008. A chemical approach to stem-cell biology and regenerative medicine. Nature 453: 338-344.

Yamanaka S. 2009. Elite and stochastic models for induced pluripotent stem cell generation. Nature 460: 49-52.

Yamanaka S, Blau HM. 2010. Nuclear reprogramming to a pluripotent state by three approaches. Nature 465: 704-712.

Young MA, Larson DE, Sun CW, George DR, Ding L, Miller CA, Lin L, Pawlik KM, Chen K, Fan X, et al. 2012. Background mutations in parental cells account for most of the genetic heterogeneity of induced pluripotent stem cells. Cell Stem Cell 10: 570-582.

Yu J, Vodyanik MA, Smuga-Otto K, Antosiewicz-Bourget J, Frane JL, Tian S, Nie J, Jonsdottir GA, Ruotti V, Stewart R, et al. 2007. Induced pluripotent stem cell lines derived from human somatic cells. Science 318: 1917-1920.

Zhao XY, Li W, Lv Z, Liu L, Tong M, Hai T, Hao J, Guo CL, Ma QW, Wang $\mathrm{L}$, et al. 2009. iPS cells produce viable mice through tetraploid complementation. Nature 461: 86-90.

Zhou Q, Brown J, Kanarek A, Rajagopal J, Melton DA. 2008. In vivo reprogramming of adult pancreatic exocrine cells to $\beta$-cells. Nature 455: 627-632.

Zhou H, Wu S, Joo JY, Zhu S, Han DW, Lin T, Trauger S, Bien G, Yao S, Zhu Y, et al. 2009. Generation of induced pluripotent stem cells using recombinant proteins. Cell Stem Cell 4: 381-384. 


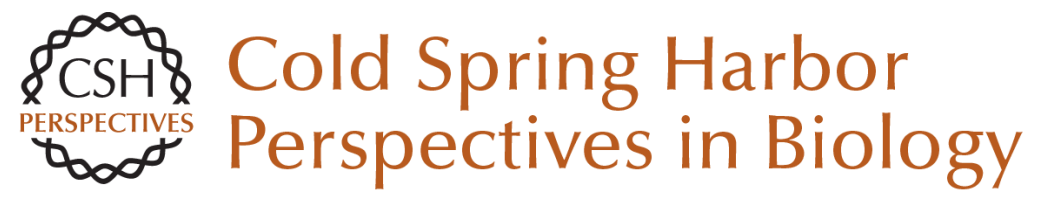

\section{Induced Pluripotency and Epigenetic Reprogramming}

Konrad Hochedlinger and Rudolf Jaenisch

Cold Spring Harb Perspect Biol 2015; doi: 10.1101/cshperspect.a019448

Subject Collection Epigenetics

Metabolic Signaling to Chromatin Shelley L. Berger and Paolo Sassone-Corsi

Histone and DNA Modifications as Regulators of Neuronal Development and Function Stavros Lomvardas and Tom Maniatis

Histone Modifications and Cancer James E. Audia and Robert M. Campbell

Epigenetics and Human Disease Huda Y. Zoghbi and Arthur L. Beaudet

Induced Pluripotency and Epigenetic Reprogramming Konrad Hochedlinger and Rudolf Jaenisch

Long-Range Chromatin Interactions Job Dekker and Tom Misteli

RNAi and Heterochromatin Assembly Robert Martienssen and Danesh Moazed

Dosage Compensation in Drosophila John C. Lucchesi and Mitzi I. Kuroda
Epigenetic Determinants of Cancer Stephen B. Baylin and Peter A. Jones

Maintenance of Epigenetic Information Geneviève Almouzni and Howard Cedar

A Structural Perspective on Readout of Epigenetic Histone and DNA Methylation Marks Dinshaw J. Patel

The Necessity of Chromatin: A View in

Perspective Vincenzo Pirrotta

Germline and Pluripotent Stem Cells Wolf Reik and M. Azim Surani

Comprehensive Catalog of Currently Documented Histone Modifications Yingming Zhao and Benjamin A. Garcia

Epigenetic Regulation of Chromatin States in Schizosaccharomyces pombe Robin C. Allshire and Karl Ekwall

Histone Variants and Epigenetics Steven Henikoff and M. Mitchell Smith

For additional articles in this collection, see http://cshperspectives.cshlp.org/cgi/collection/

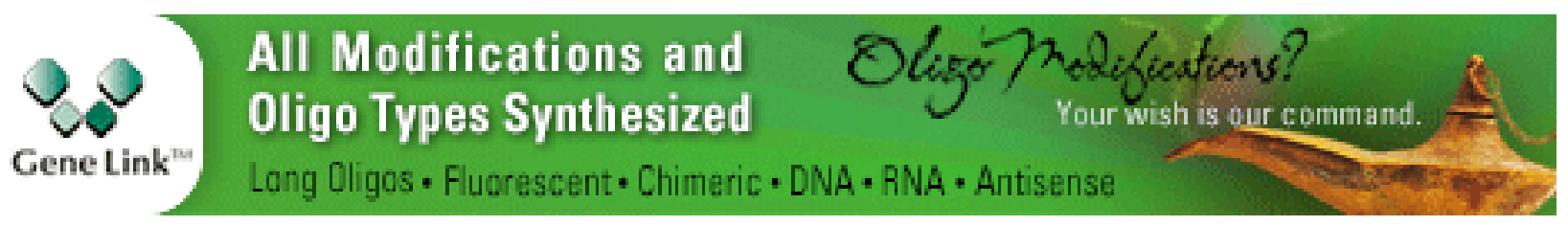

Copyright @ 2015 Cold Spring Harbor Laboratory Press; all rights reserved 
For additional articles in this collection, see http://cshperspectives.cshlp.org/cgi/collection/

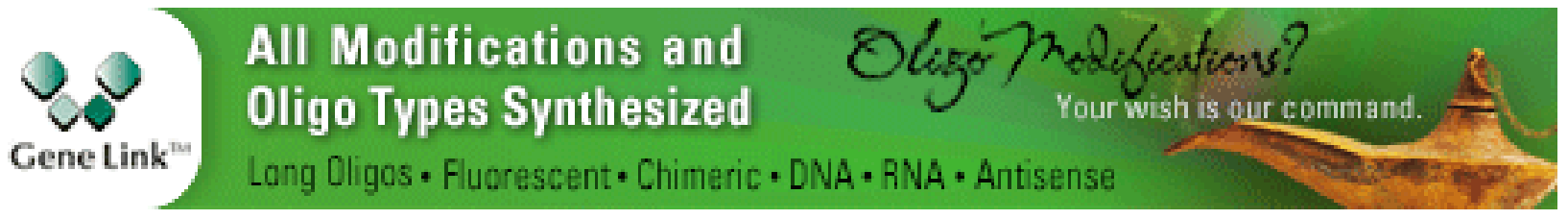

Copyright @ 2015 Cold Spring Harbor Laboratory Press; all rights reserved 